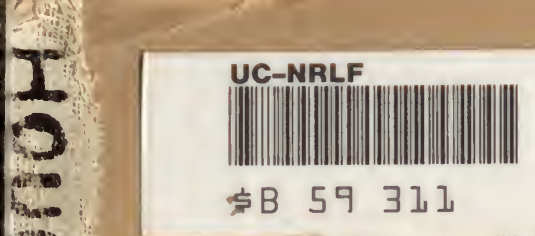

$\eta$

0

0

UC-NRLF 


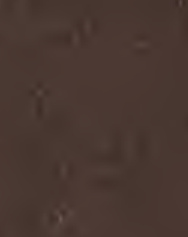

Sin

(1) $y=$

ins $8 \quad 11$

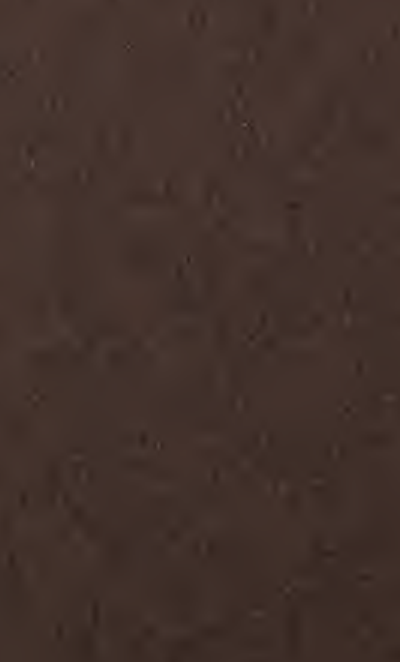


$\therefore$ 


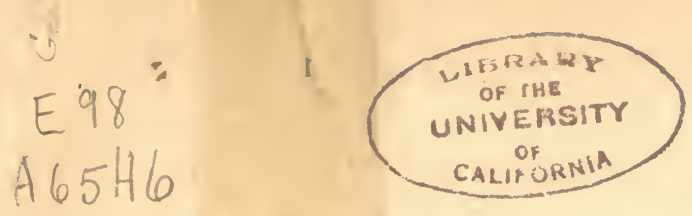

\title{
PRIMITIVE AMERICAN ARMOR
}

By Walter Hovgh, Ph. D.,

Department of Ethnology, U. S. National Museum.

\begin{abstract}
"Cornelius Tacitus doth pleasantly quip and jest at the men of war of" our ancient Gaules, so armed, only to maintaine themselves, as they that have no means either to be offended or to raise themselves being overthrowne." Montaigne, Of The Parthian Armes.
\end{abstract}

In the U.S. National Museum there are many examples of primitive American armor. These defensive weapons may be classed as parrying: armor, or the shield, and body armor, for the defense of the head, trunk, legs, and arms. The subject will be treated under form, material, structure, decoration, function, mythology, and distribution.

\section{SHIELd.}

The shield is the first defensive weapon both in point of time and of usefulness. While the shield on first thought may seem merely intended as a covering for the vulnerable points of the body, its importance is far greater in parrying. Therefore, with this idea in view, the shield may be as simple as the plain parrying stick of the Australians, which begins the classic series of Lane Fox.

If one bears in mind that defensive weapons are the concomitants of oftensive weapons, the development of the shield becomes clear. 'Thus, where missile weapons are used, the parrying stick is a natural and adequate defense. Where missiles are given greater velocity with the throwing strap, the throwing stick, or the bow, the shield must cover the body better. It would seem that the broad shield is the countergrowth of the bow.

The circular shield characterizes the Western Hemisphere. The North American shield is eonvex and from 12 to 26 inches in diameter. The Mexican area is perhaps an exception, though the Codices almost invariably depict the round shield, and the surviving Mexican shields, on which Mrs. Zelia Nuttall is authority, are circular.* The Nahua shield was "sometimes rounded and sometimes oval, sometimes rounded on the lower side." Some shields were of an ordinary size; others were intended to cover the entire body and were constructed so that when not in use they could be folded up and earried under the arm. $\dagger$ Lafitau conveys the idea that the Iroquois had shields of different shapes.t

As to rnaterial, nearly all American shields are made of thick rawhide, that of the buffalo and elk being most available. Shields worked

*Nuttall, Zelia, on Ancient Mexican Shields. Internat. Archiv. fur Ethnologie, ،eitlen, Vol. v, pt. I, 1892, pp. 34-53.

† Bancroft, II. H., Native Races of the Pacific, Vol. Ir, p. 407.

t Tafitau, Mours des Sauvages Aurrirguans, Vol. 11, p. 197, Paris, 1724. 
out from a single piece of wood, like those of the Dyaks are found on the Rio Marañon in South America (fig. 1).*

The Virginia Indians used "targets made of barcks." $\dagger$ The Navajoes made a shield of cedar rods twined together with eord (Cat. No. 8401 , U.S.N.M.), which may be connected with the rod armor of the Athapascans and the similar cane shields of the Nahuas of Mexico.

Among the Ceris and Chieoratos of New Mexico, "Another kind of shield was marle of small laths closely interwoven with cords, in such a manner that, when not required for use, it could be shut up like a fan, and was carried under the arm." $\ddagger$

"In Tobaseo and along the coast, tortoise shells inlaid with gold,

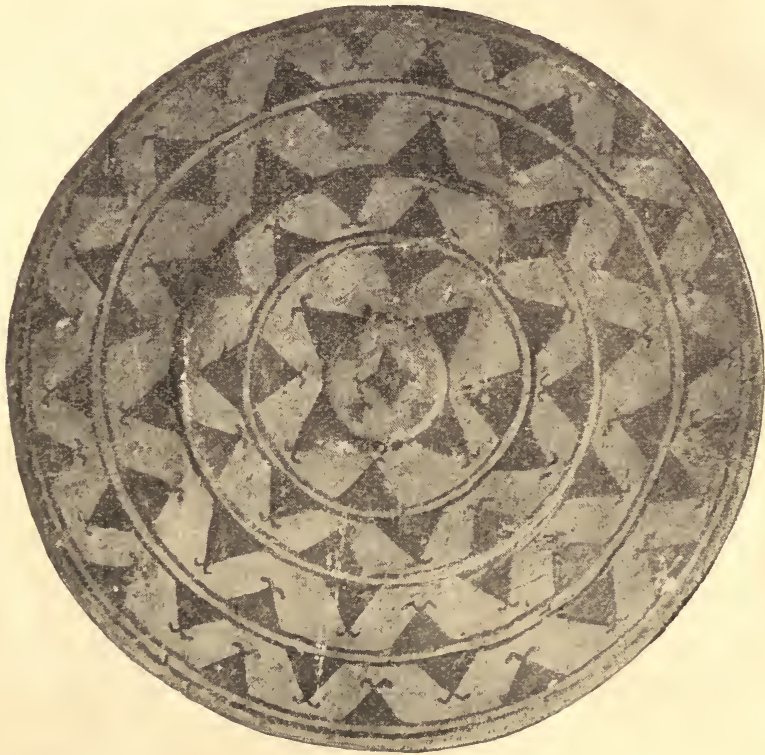

Fig. 1.

WOODEN SHIELD.

Cat. No, $75 \times 81$ U. S. N. M. Peru. Gift of the Trocadero Museum, Paris.

silver, or copper were commonly used as shields," $\$$ as the Malay specimen from Singapore. Reeds, grass, hides, or 'nequen-cloth coated wit! India rubber served to protect an Aztec common soldier.|l The Preblo tribes "carried round shields of basketry, of heavily and closely netted cotton, or- of thick rawhide, symbolically painterl." I

* Wooden shield. - Flat disk of light wood, thicker in the center, forming a step. Two bent wool handles wrapped with bark are sprung into holes in the rear of tho shield. Deeorated with triangular figures in red and yellow, resemblingtents. Diameter, 33 inches. (Cat. No. 75881, U. S. N. M. Indians of the Upper Amazon (Rio Marañon) Perı. Gift of the Trocadero Museum, Paris).

t Hariot, Thomas, Virginia, p. 24.

‡ Bancroft, op. cit., Vol. I, 1. 579.

§ Bancroft, H. II., op. cit., Vol. II, p. 407.

II Baneroft, loc. cit.

TCushing, F. H., article "Puel,los," in Johnson's Cyclopedia, from adranced sheets in new edition, now in press. 
OF THE

The construction of the North American shield is given in detail by George Catlin. The ingenious process of contracting and hardening the hide by fire was common.

Sioux shield made of the skin of the buffilo's neck, hardened with glue extracted from the hoofs and joints of the same animal. The process of "smoking the shield" is a very curious as well as important one, in their estimation. For this purpose a young man about to construct for him a shield digs a hole of 2 feet in depth in the ground, and as large in diameter as he desigus to make his shield. In this he builds a fire, and over it, a few inches higher than the ground, be stretches the rawhide horizontally over the fire, with little pegs driven through holes made near the edges of the skin. The skin is at first twice as large as the size of the required shield; but having got his particular and best friends (who are invited on this occasion) into a ring to dance and sing about it and solicit the Great Spirit to instill into it the power to protect him harmless against his enemies, he spreads over it the glue which is rubbed and dried in, as the skin is heated; and a second busily drives other and other pegs, inside of those in the ground, as they are gradually giving away and being pulled up by the contraction of the skin. By this curious process, which is most dexterously done, the skin is kept tight whilst it contracts to one-half of its size, taking up the glue and increasing in thickness until it is rendered as thick and hard as required (and his friends have pleaded long enough to make it arrow, and almost ball, proof), when the dance ceases and the fire is put out. When it is cooled and cut into the shape that he desires, it is often painted with his medicine or totem upon it, the figure of an eagle, an owl, a buffalo, or other animal, as the case may be, which he trusts will guard and pro-

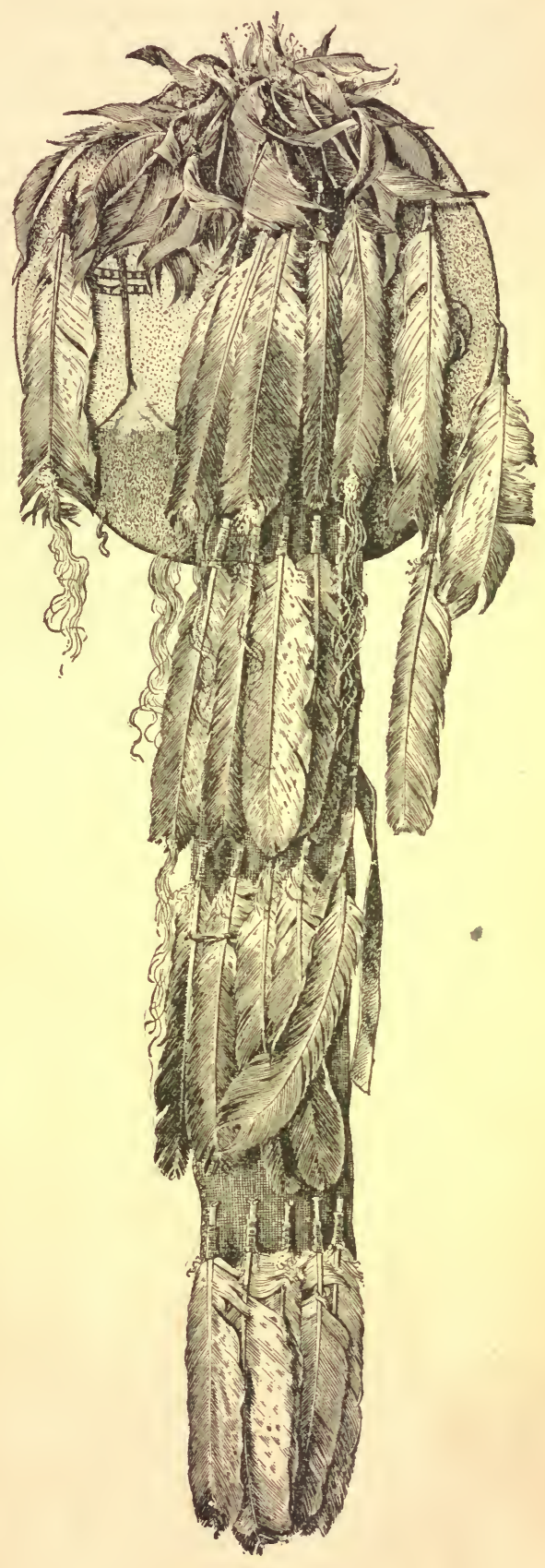

Fig 2.

ARAPAHOE SHIELD.

Cat. No. 129871, U. S. N. M. Dakota. Collected by H. M. Creel, tect him from hark. It is then fringed with eagles' quills or other ornaments he 
may have chosen and slung with a broad leather strap that crosses his breast. These shields are carried by all the warriors in these regions, for their protection in battles, which are almost invariably fought from their horses' backs. *

The shield was invariably held on the left arm, $\dagger$ usually by a simple thong of buckskin attached to the interior. Wooden handles, believed to have belonged to Pima Indian shields, were found in a cave with war clubs on Superstition Mountain in Arizona, by Dr. E. Palmer. (Cat. No. 76028, U. S. N. M.)

It is the custom of most tribes to put one or more covers of dressed buckskin over the shield, the covers being decorated. $\neq$ (See. pl. I and fig. 2.)

The decoration of the North American shield forms one of the most fruitful sources for the religious beliefs and practices of the Indians.§

The decoration was inspired by a revelation through a dream, follow. ing among the Crows the terrible initiation ceremony and among all tribes following an ordeal. The protection of the shield has largely become fetichistic and in many cases the survival of this ancient means of defense has been brought about by its cult relations.

The warrior fraternities of the Moki and Zuñi tribes have an elaborate ceremonial of the shield.|l In the Moki ceremony, held at the

* Catlin, George, North American Indians, 7th ed. Lond., 1848. Vol. I, p. 241.

† See the paper by Mr. Cushing on Manual Concepts., American Anthropologist, v, 1892 , p. 290.

$\ddagger$ DESCRIPTION OF FigURE 2 AND PLATE $I$.

Fig. 2, shield.-Made of rawhide with cover of muslin symbolically painted in green, yellow, red, and black. The background above is yellow and below green. The figures are on the yellow portion and represents two dragon flies, the sun and moon, an owl, and a circle in red outlined with green. Two eagle claws are fastened at opposite sides. A bunch of eagle feathers is fastened at the upper edge, and from it depends a flannel band with rows of large eagle feathers having horsehair cementerl to their ends. The thongs for holding have disappeared; there remains a thong for suspension. Diameter 18 inches (Cat. No. 129871, U.S. N. M. Arapahoe Indians, Dakota. Collected by H. M. Creel.)

Plate I, shield with 2 covers. - The shield proper is of hardened buffalo hide of convex form, plain in front with four perforations through which the thong forming the handle is passed, (lower figure). To the triangular handle are attached long cow tails, (figure to right). The inner cover is of buckskin, gaudily decorated, and edged with a band of flannel bordered with eagle feathers and having a woven band hanging down, (figure to left; back view of same, upper figure to the right). The outer cover, which is to protect the inner cover and the feathers are also painted and whitened with pipeclay. Four charms are attached to it, viz, a eurl of cow's tail, an eagle feather, and two tufts of shredded cloth with a bit of brass chain. The covers are gashed around the edge and supplied with a gathering string for securing the cover tightly over the shield. The complete shield is shown in the upper figure to the left. A third painted cover for this shield has been discovered. Diameter of shield proper, $15 \frac{1}{2}$ inches; of shield with covers, $17 \frac{1}{2}$ inches. (Cat. No. 8443, U. S. N. M. Comanche Indians, Fort Griffin, Texas. Collected by Dr. H. McElderry, U. S. A.)

$\S$ Mr. James Mooner is preparing a paper upon this branch of the subject. Mrs. Nuttall has treated on this aspect of the Mexican shield; loc. cit., ante, p. 1.

|| See Zuñi Fetiches, Cushing, 2d Au. Rept. Bu. Ethnol., Pls. x, XI, p. 4 U. 
1. 3

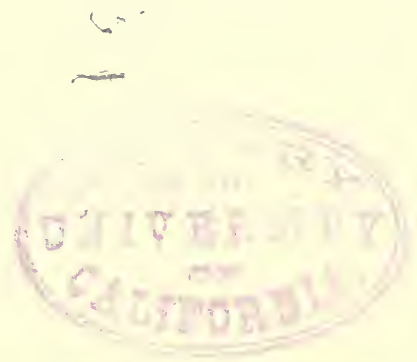


winter solstice by the warrior societies, the sun is represented by a shield, and attack and defense is graphically dramatized. The shields of the sun warrior fraternities are decorated with the totems of the individnal societies. A description of this ceremony will soon be pub. lished by Dr. J. Walter Fewkes.

The various feathers, hoofs and horns, and skins of animals, etc., hung to shields, are also personal fetiches.

The distribution of the shield shows that most of the American tribes possessed the shield, and a majority appear to have had no other weapon of defense. There is strong presumption, however, that the use of body and shield armor was widespread in America, as historical notices show.

Charlevoix, writing of the Iroquois, observes that while the western tribes use bucklers of buffalo hicle, "it is pretty surprising that other Indian nations never use them."* Lafitau and the earlier missionaries, however, eredit the Iroquoian people with the shield in the following words:

Their shields were of ozier or bark covered with one or many peaux passées; there are some made of very thick skin. They had them of all sizes and all sorts of figures.t

Some South American tribes who use body armor are said to be unacquainted with the shield. Likewise the Eskimo seem to be destitute of this weapon.

There are probably fifty American shields in the National Museum, some collected as early as 1830 . Several have been handed down from father to son for a period of sixty-five years.

These shields are from the tribes of the western portion of the continent and include the Crows, Sioux, Comanches, Kiowas, Navajoes, Utes, Apaches, Pimas, Zuñis, Mokis, etc.

\section{BODY ARMor.}

The aboriginal armor of North America was intended to protect the vital organs and to allow free-movement of the limbs. The form assumes that of a skeeveless jacket, coat, or wide band going around the trunk, suspended from the shoulders. The selection of defensive materials and their adaptation to defensive covering for the body form an interesting study in native invention, while the evidence in North America of the migration of inventions awakens no less interest. Thus we find that at the period of the disuse of armor by the aborigines there were six types of body armor found on the North American Continent and contiguous regions, viz:

Plate armor.-Rows of overlapping plates, perforated and lashed. Eskimo and Thukchis.

${ }^{*}$ Charlevoix, F. X. de, Journal of a Voyage to North America. Vol. I, p. 338. Lond., 1761.

† Latitau, loc. oit., Ir, p. 197. 
Slat armior.-Wooden slats twined together. Sitkans, Shastas, Iroquois, Virginia Indians.

- Rod armor.-Wooden rods twined together. Aleuts, Sitkans, Colum bia River tribes, Klamaths, Hupas, Iroquois, Virginia Indians, etc. Band armor.-Bands of skin arranged in telescoping fashion. Clıukchis.

"Skin armor.-Coats of hardened hide. Tlingits, Haidas, Hupas, Chinooks, Navajoes, Mohàwks, Shoshones, Pawnees, Comanches, etc.

Cotton-padded armor.-Mexicans, Isthmians, and Peruvians.

Three well-defined areas, including the above-mentioned types of North American body armor, will be now considered, viz:

(1) Bering Strait area, the American shore of Bering Sea, and the islands as far north as Cape Prince of Wales, inhabited by the Eskimo, and the Asiatic side, inhabited by the Coast Chukchis. (Plate armor.)

(2) Western area, extending from Sitka through northern California and the central basin to Mexico. (Slat, rod, and skin armor.)

(3) Eastern area, extending from southeastern Cauada to Virginia, inhabited by Algonkian and Iroquoian tribes. (Slat, or rod, and skin armor.)

The first two areas are known by actual specimens, while the third area is historical. In the interior of the continent, according to historical notices, several stocks used armor. There is, therefore, sufficient testimony to show that if not universal the use of armor was at least general among the North American tribes.

\section{BERING STRAIT AREA.}

The National Museum possesses a number of examples of EskimoChukchis plate armor from Cape Prince of Wales, Diomede Island, St. Lawrence Island, Alaska, and Cape Wankarem, Siberia.

The most perfect specimens are from Cape Prince of Wales and Diomede Island. (See pls. 2 and 3.)*

* Description of plate 2.

Fig. 1, plate armor.-Made of three rows of walrus-ivory plates, averaging 1 inch in width and 6 inches in length. Each plate contains 6 holes, through which pass rawhide thongs, thus lashing the plates together. These plates are slightly imbricated, as are also the different rows, so as to ward off more effectually the weapous of the enemy. The lower row contains 43 plates, and the middle 38 . The upper row consists of two sections; one containing 10 plates, protecting the breast, the other 8 plates, protecting the upper part of the back. A rawhide strap passes over the shoulders and supports the armor. This armor very closely resembles that of Japap. Length when spread out, 44 inches. (Cat. No. 153491, U.S.N.M. Eskimo of Cape Prince of Wales, Alaska. Collected by H. R. Thornton).

Fig. 2, plate armor.-Fragment consisting of 9 iron plates similar to those on Japanese armor, and bound with three lashings of rawhide. This speciman was 

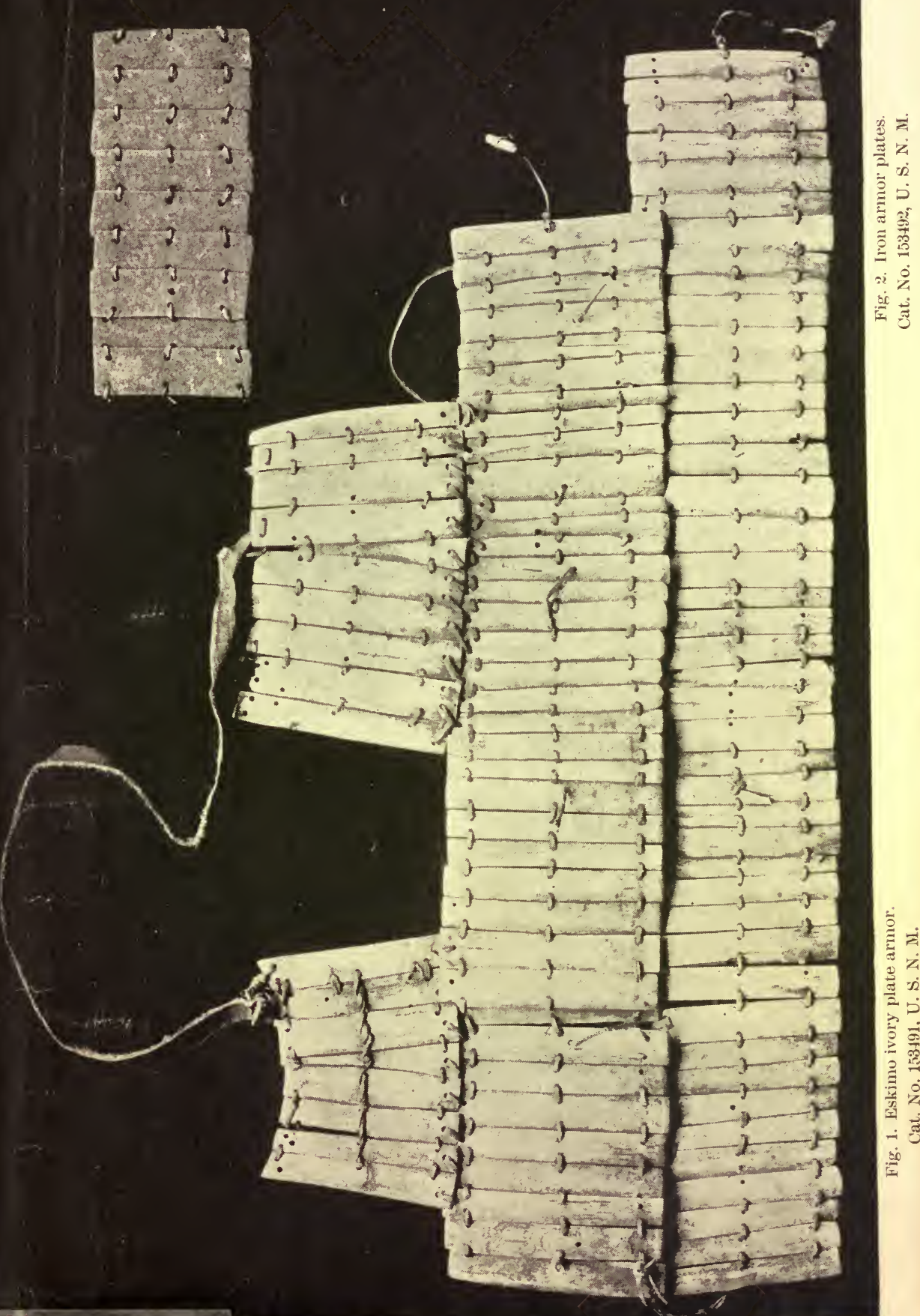
has been much discussion.* The upper portion of this war panoply (yl. $4,+$ fig. 1 ) is unique.

It serves as a shield and resembles the neck fender of the Kingsmill Island armor; designed, without doubt, to protect the warrior from attack in the rear, a common occurrence in all savage warfare.

The whole armor is very heavy and clumsy. The method of wearing the suit is shown in plate 5. Captain Hooper says:

Their war spears and those used in hunting bears are made of steel, with a hancle about 6 feet long. The blade is kept very sharp and highly polished. These weapons are often beautifully inlaid with brass ornamented figures, and are purchased from the Russian traders at Gazhaga. $\oint$

The Chukchis of Plover Bay formerly wore a cuirass made of long strips of baleen, reaching from the neck to the middle of the thigh. The thickest baleen was not selected for making the armor. The strips were arranged vertically, en echelon, and tied through perforations on the edges. Over the joints were applied other strips of whalebone, as in a thatch fastened by thongs, passing through perforations at their edges and in the middle of the foundation strips. Owing to the material and construction this armor was somewhat elastic. When spread out it was in shape of a band with cuts below the armpits and having suspending straps going over the shoulders, resembling the Hupa armor. (See pl. 15.) The coat was tied at the back with cords, requiring the assistance of another person.

The Chukchis told my informant, Capt. E. P. Herendeen, that this

* Hewitt, John, Ancient armor, p. 270; also hoop armor, id. p. 256.

† DESCRIPTION OF PLATE 4.

Fig. 1, armor.-Upper portion of 2437. Marle of sea-li on skin stretched over plates of wood. Back, shield shaper, formed of 2 vertical pieces of three-eighth inch board lashed together with whalebone and covered with hide, which extends continuously over the wings, being a very large skin turned over and sewed on the npper edge. The wings consist of 4 wooden plates on one side and 5 on the other, growing shorter toward the front and terminating on the left side in a section without wooden lining. The plates are movable, the hide being creased at the joints and in the crease is laid a rounded thong which is held at intervals by loops of whalebone passing through the edges of the plates. On the back are two whalebone toggles for attachment to the lower portion. A more clumsy contrivance than this fender can scarcely be imagined. Width, 72 inches; height, 28 inches. (Cat. No. 2436, U.S.N.M. Chukehis, Eastern Siberia. Collected by Commodore John Rogers, U. S. N.

Fig. 2, hoop armor.-Made of seven bands of sea-lion skin, $5 \frac{1}{2}$ inches wide, doubled and whipped together at the edges. These bands are conneeted by heavy thongs and hang in an enlarging series, like an inverted telescope drinking cup, from a frame of whalebone covered with hide. The free ends of the bands overlap in front. A square breastplate of doubled hide protects the neck. This armor is the lower portion of No.2436. Diameter, 36 inches; height, 20 inches. (Cat, No. 2437, U.S.N.M. Chukchis, Eastern Siberia. Collected by Commodore John Rogers, U. S. N.

$\ddagger$ DESCRIPTION OF PLATE 5 .

Chukchis varrior and family.-From an aquarelle made by W. Alexander in 1797, showing, after the interpretation of the artist, the method of wearing the armor figured in pl. 4.

$\oint$ Cruise of the Corwin, 1881, Washington, 1884, p. 31. 

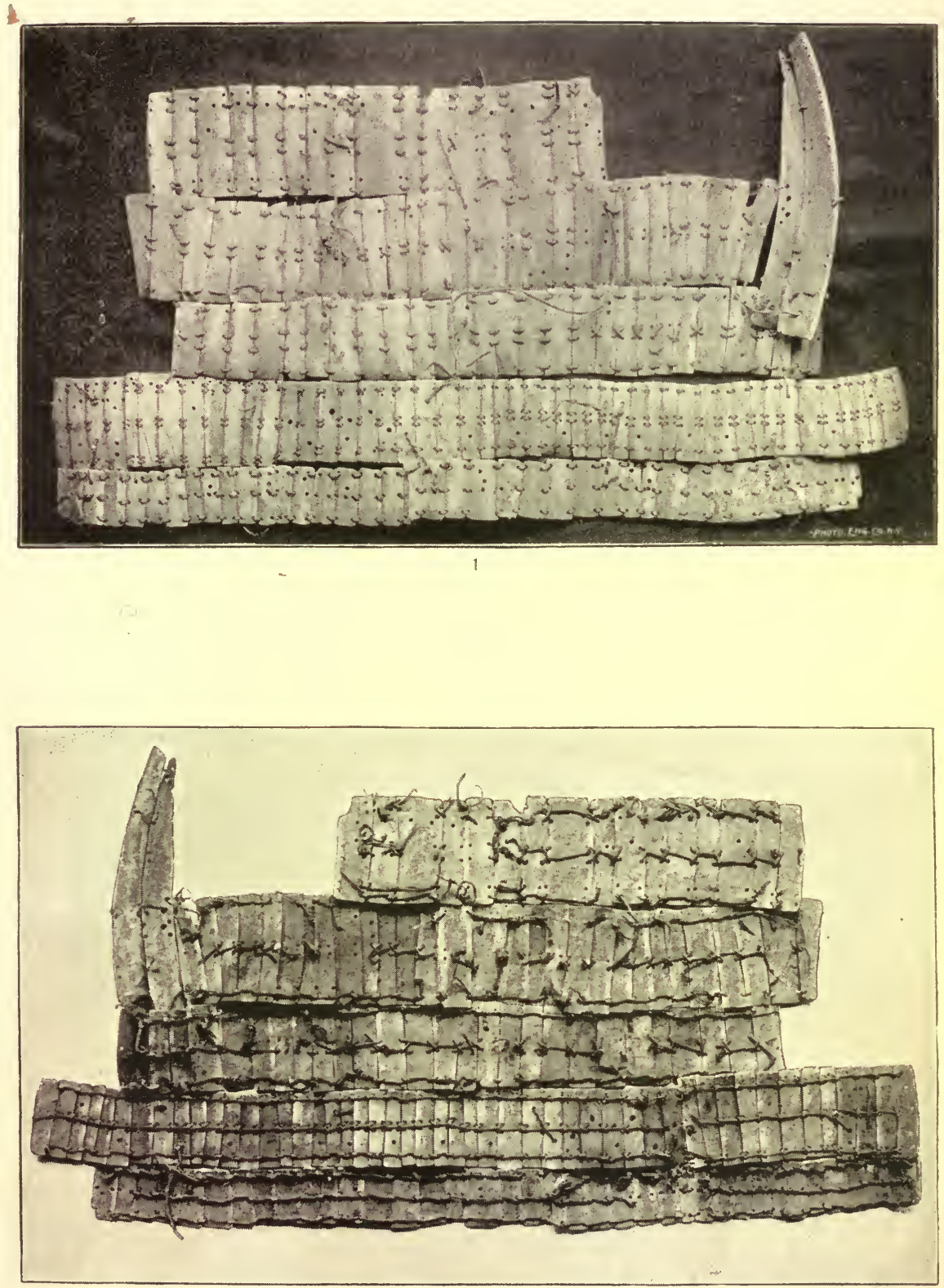

2

Eskimo Plate ARMOR.

Fig. 1. Front view ,
Fig. 2. Back view , 
<smiles>C1CCCC1</smiles>
Gevaros 

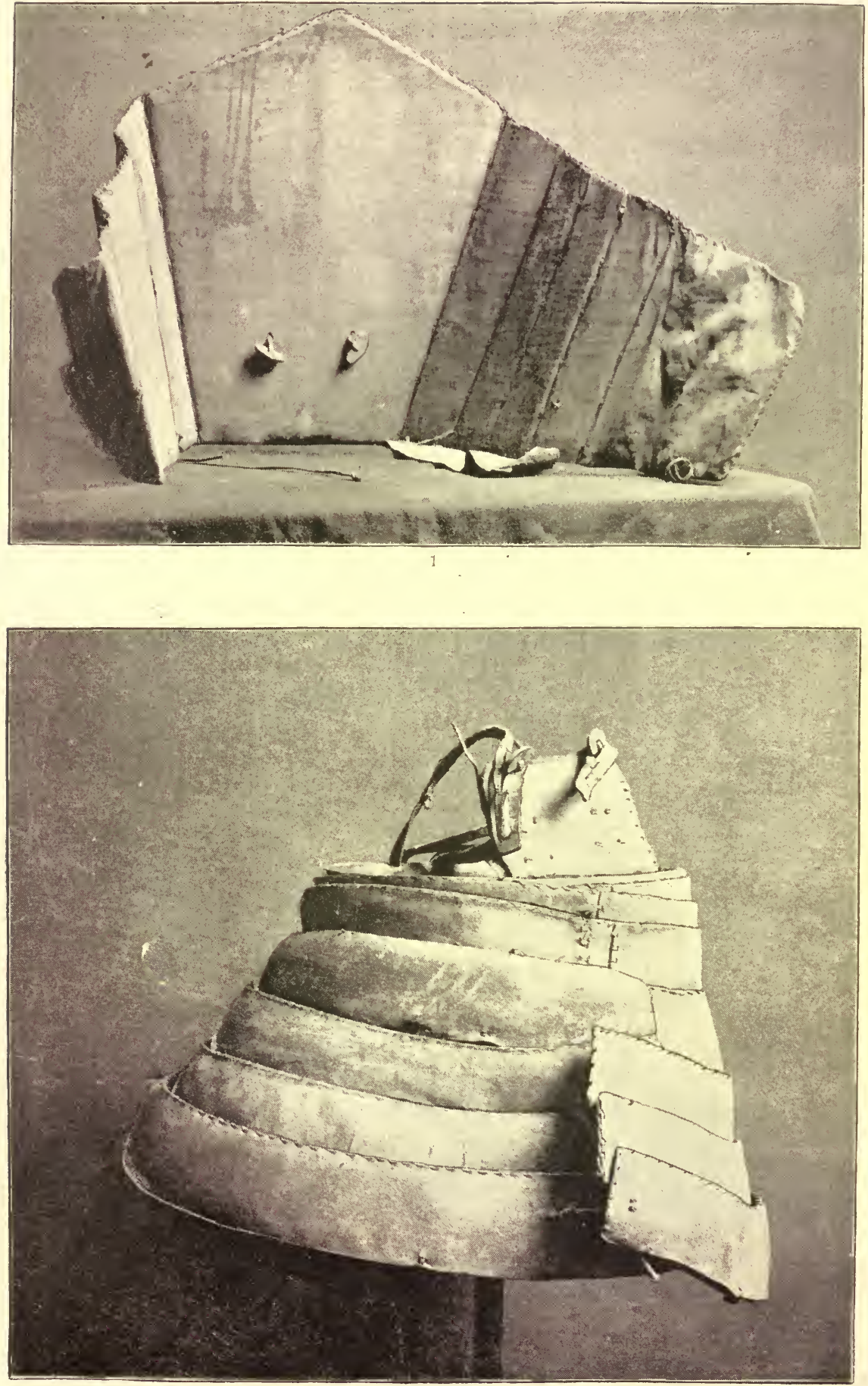

CHUKCHIS HOOP ARMOR.

Fig. 1. Upper portion. Cat. No. 2436, U. S. N. I

Fig, ¿. Lowel portion. (Uat. No, 24:3ð, U. S. N. M. 



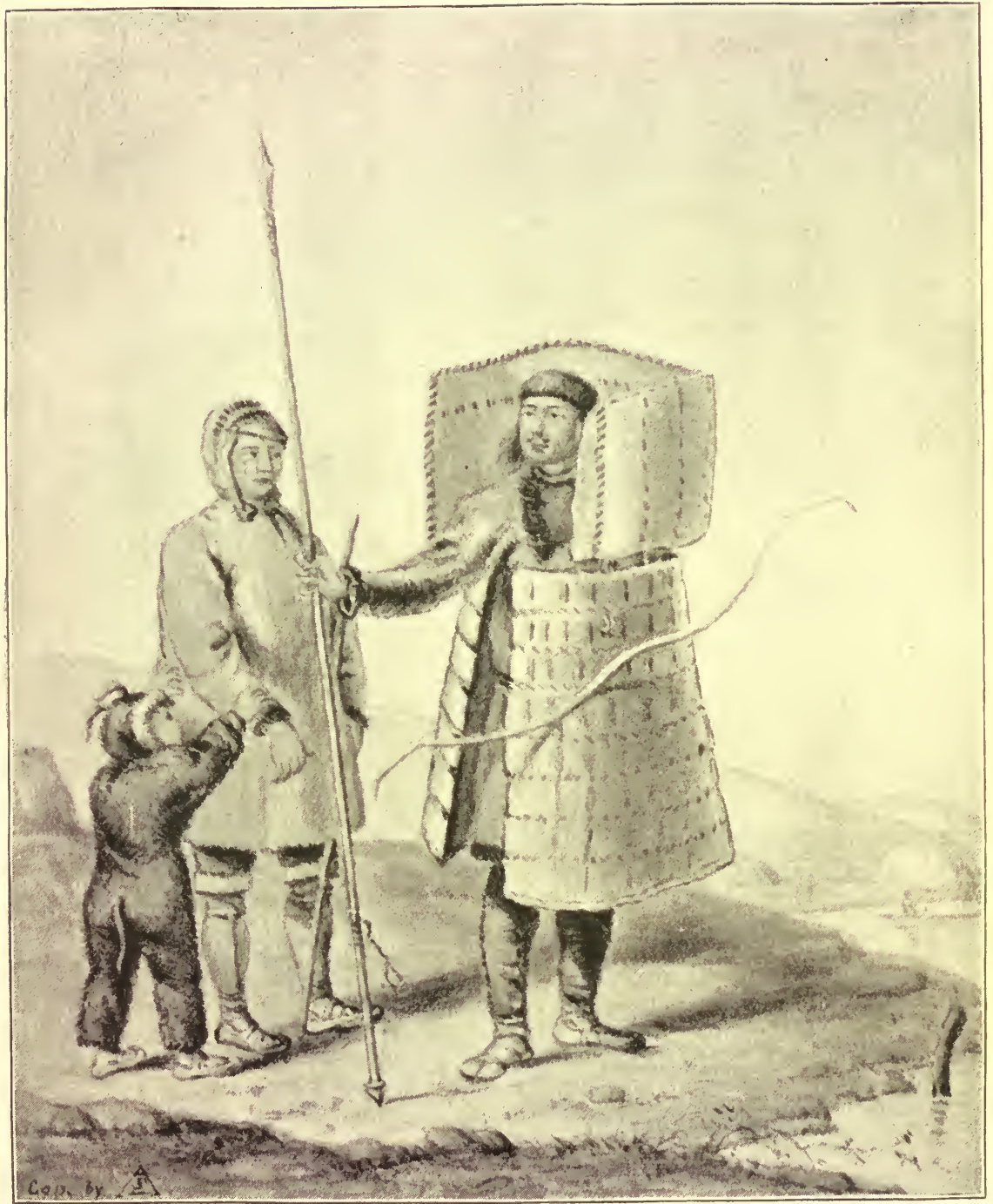

Chukchis wearing hoop armor. Plover bay. 


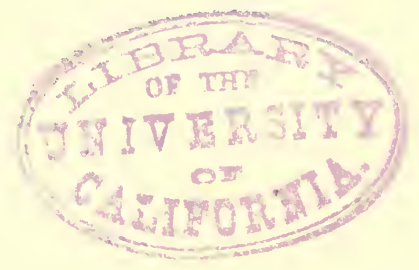


armor was used in going over to trade with the hostile Eskimo of St. Lawrence Island, which was dangerous and compelled sleepless caution. Capt. Herendeen also saw the band armor (pl. 4) among the Chukchis. Ivory was not observed by Capt. Herendeen, as that material is very scarce on the Asiatic side; but, no doubt, the materials for plate armor were procured by barter with

Eskimo. In any event, fossil ivory plate armor was made by the Chukchis.

Driftwood is also very rare on the Siberian coast, while on the islands and American shore it is abundant. The quest for this indispensable material must liave been a strong incentive for the A siatic migrants to cross the straits.

As far as kuown the Chukchis did not use either helmets or shields.

Of interest in comparison with the Eskimo-Chukchis armor is that used by the Giliaks of Siberia. 'This is composed of plates of iron lashed together (fig. 3).*

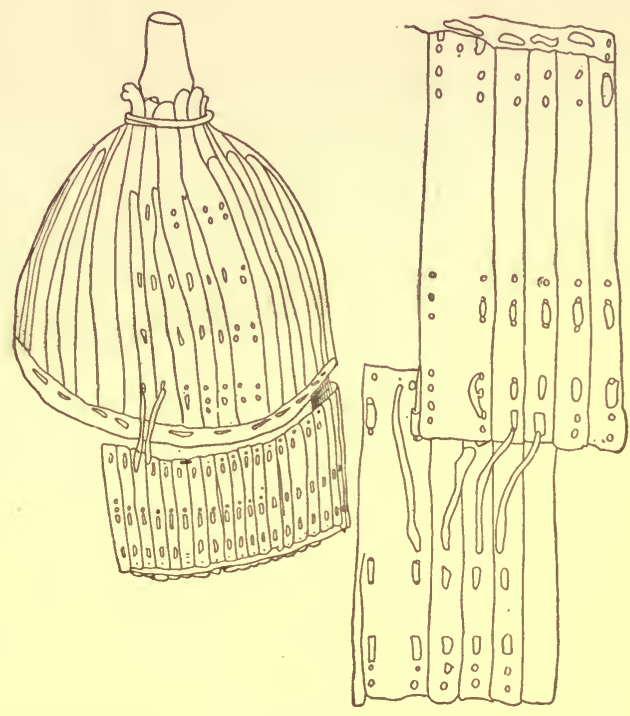

Fig. 3 .

GILIAK HELMET AND BODY ARMOR. SIBERIA.

Aftor Schrenck.

They also wear an ingeniously constructed conical helmet with a neck cover. The Giliak coat of plaited thougs, figured in the same work, does not occur in America, but has its counterpart in the cocoanut-fiber armor of the Polynesians and the plaited armor of the Malays.

The Kamtschadales have bows, arrows, spears, and a coat of mail made of mats or plaited thongs. $\dagger$

The Kalmuckss have coats of mail bought from their neighbors.t They use lances.

Descending the coast toward Japan. which seems to be the origin of the plate armor ranging from that country into the American continent, we notice that the Colletske make use of a leather coat covered with plates of iron about 6 inches long and a pot-shaped helmet of smaller plates having neck covers.

*Schrenck, L. V., Reisen und Forschungen im Amur-Lande, 1854-'56. St. Petersburg, 1891. Pl. XLIV.

Description of fig. 3.--Helmet and detail of armor of the Giliaks of the Amoor, Siberia. In the perforations and arrangement this armor resembles the armor of the Eskimo.

Drawing from Reisen und Forschungen in Anur-Lande, 1854-'56, by Dr. Leopold V. Schrenck. St. Petersburg, 1891.

$\dagger$ Grieve, Hist. of Kamtschatka, Gloncester, 1764, p. 202

$\ddagger$ Pallas, 1, p. 143. 


\section{WESTERN AREA.}

In the western area the slat type of wooden armor seems to be cen tral among the Koluschans in the north, while the rod type runs southward and is central among the Tinné of British Columbia.

The slat armor has some resemblances to the Eskimo coat, and might be regarded as the working out of the plate-armor idea in a region where wood is abundiant and twined weaving common.

The slat coat or coat of slats and rods combined is always made in two sections, one for the front and the other for the back, while the rod coat is in a single piece.

Plate $6 *$ shows the front and back of the slat coat, and Plates 7 and $8 *$ show the combined rod and slat armor. These specimens are very old. The woodwork shows great skill, especially the interlocking joinery at the edges. The hardest wood procurable was selected, and usually sinew cord was employed to join the slats. Plate 9,* taken from Niblack after Lisiansky, shows the parts and method of wearing the slat armor.

\section{* descriptions of plates 6-9.}

Plate 6, slat armor.-Made of 32 slats of cedar and other wood woven together by tine weaving of fine sinew and other eord. A band of weaving of 3 inches width is carried along the front at the top and the weaving is continued downward in two places, meeting a band crossing the bottom and"forming a geometrical figure. The middle series of slats, 8 in number, extends below the other 4 inches, 3 of which are intact, while 2 on either side are united, forming a swallow tail and allowing the free bending of the thighs.

The front and back are distinct, joined by elk-skin cords at the sides. A section of short slats, 8 in number, is placed in front of the throat, and a similar row, 7 in number, protects the back of the neck. The armor is lield in place by a broad band of elk skin over the right shoulder, and fastened on the left side by a loop and thong. A toggle on the left side of the collar in front was probably for suspension of the quiver. Height, $21 \frac{1}{2}$ inches; width, 20 inches. (Cat. No.9243, U.S.N.M. Tlingit Indians, Sitka, Alaska. Collected by Dr. A. H. Hoff, U. S. A.)

Plates 7 and $S$, slat armor (back and front). -Made of slats and rods of hard wood $1 \frac{1}{4}$ to $1 \frac{1}{2}$ inches wide, five-sixteenths inch thick, woven together by means of fine sinew cord so as to admit of considerable flexibility. The rods and slats are pared down to form channels for the reception of the cord weaving. The front and back portions are woven separately, being counected by eords of leather on the left side and on the right siaje by a loop and toggle. The rods on the borler of the rear of armor are neatly "toed in." 'The neck portions are made up of short slats and sewed on by means of a strip of rawhide $1 \frac{1}{2}$ inches wide. 'The shoulder supports are of very thick elk hide, the one on the right being fastened by a slash and toggle. Width of rear portion, 24 inches; height, 20 inches; width of front portion, 18 inches; height, 19 inches. (Cat. No. 74437, U. S. N. M. 'Tlingit Indiaus, Sitka, Alaska. Collected by J. J. MeLean.)

Plate 9.- Wooden helmet secured to the head by straps fastened under the chin (figure in upper left corner); wooden mask or visor, side view, showing holes for eyes (middle fignre); body armor (lower left-hand figure); mask or visor, showing buckle, which is beld in the teeth to keep the visor in place (Cat. No. 74343, U.S.N.M.), Tlingit, (lower right-hand figure); sketch showing the method of wearing the armor; (upper right-hand corner). 


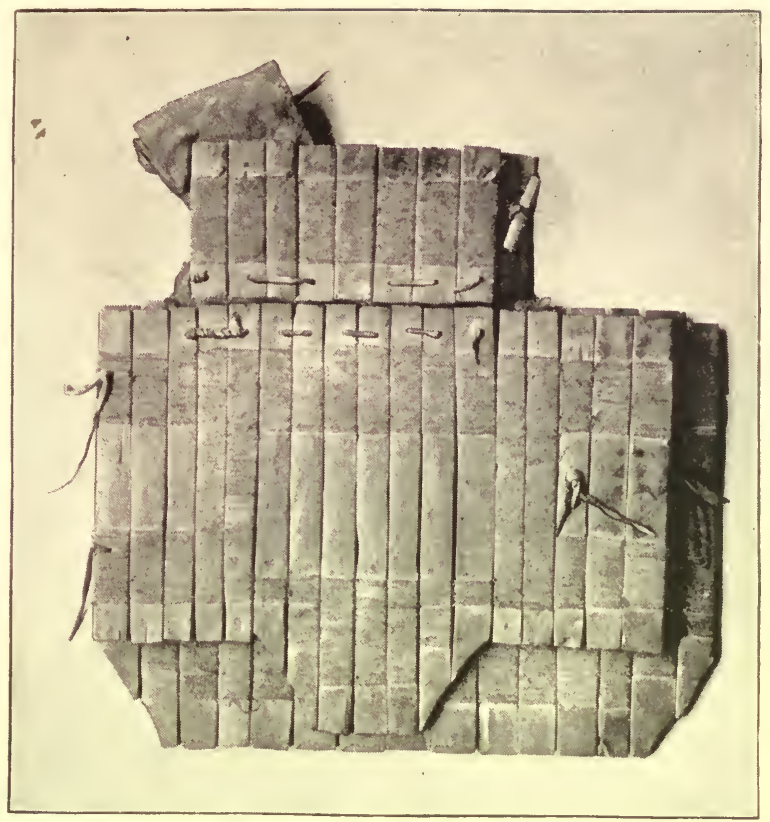

1

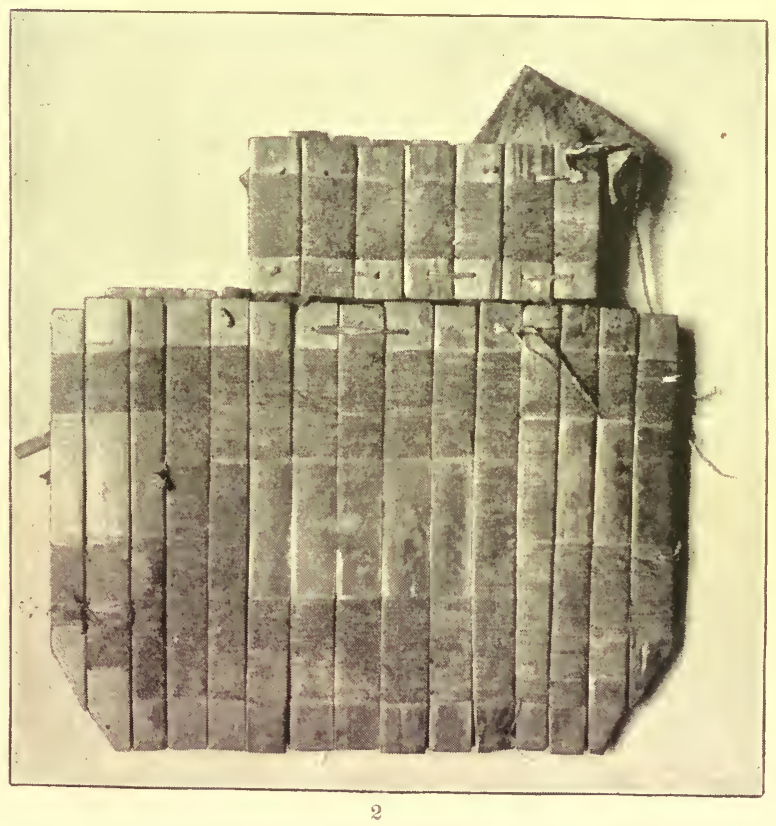

TLINGIT SLAT ARMOR.

Cat. No. 9243, U. S. N. MI.

Fig. 1. Front view

Fig. 2. Back view. 


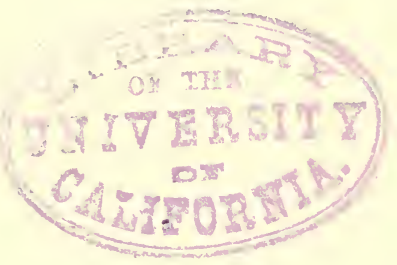




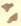

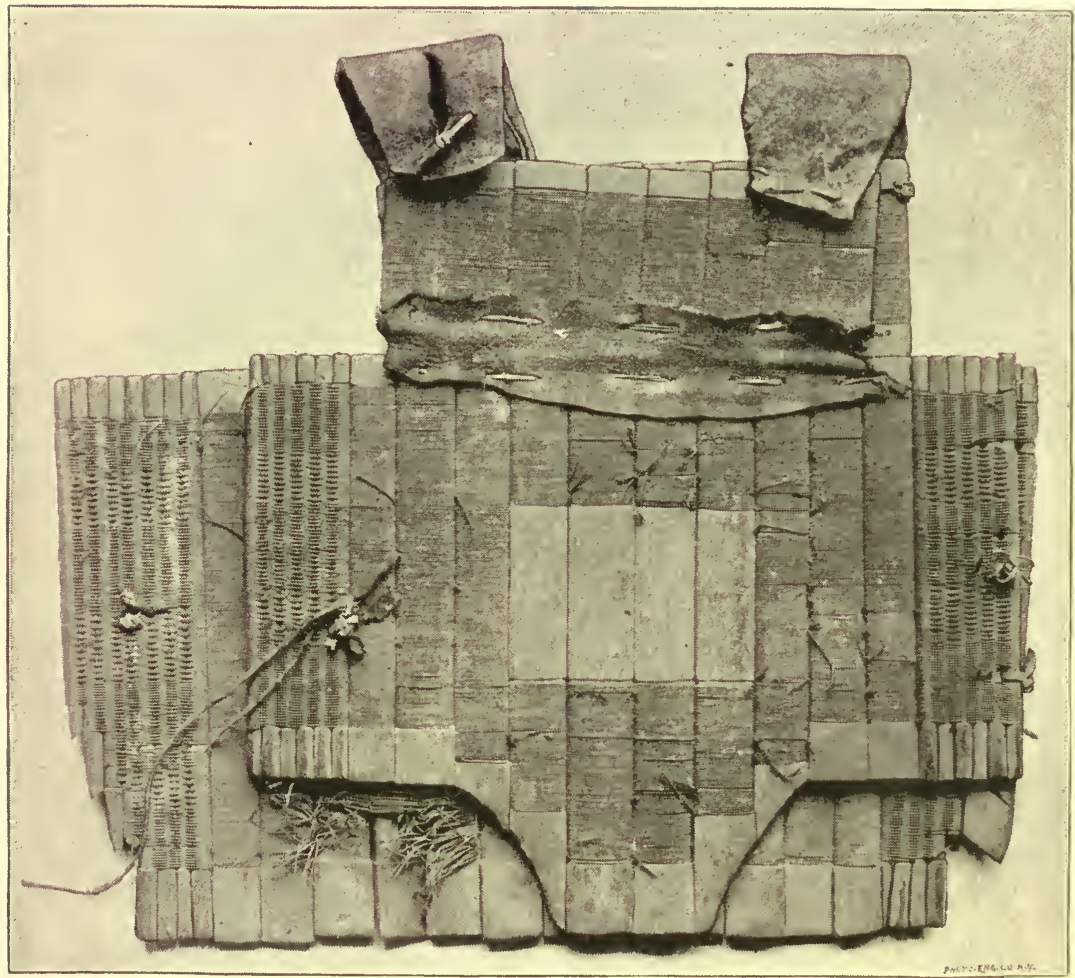

TLINGIT SLAT AND ROD ARMOR.

Cat. No. ‘443i, U. S. N. M.

Front view. 


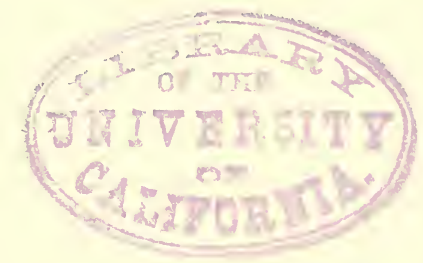




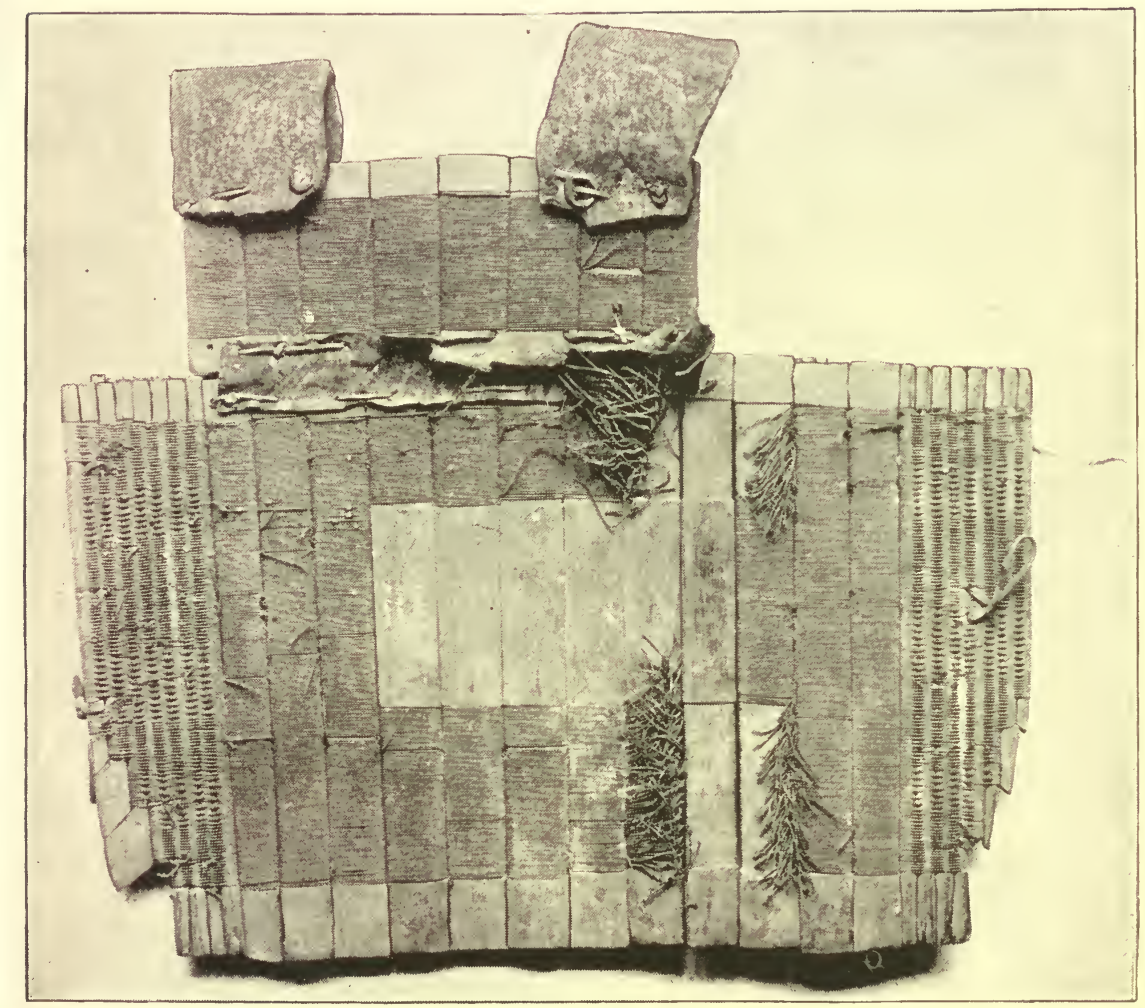

TLINGIT SLAT AND ROD ARMOR.

Cat. No. $\pi 413 \%$, U. S. N. M.

Back view. 


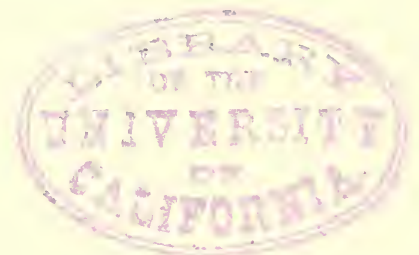




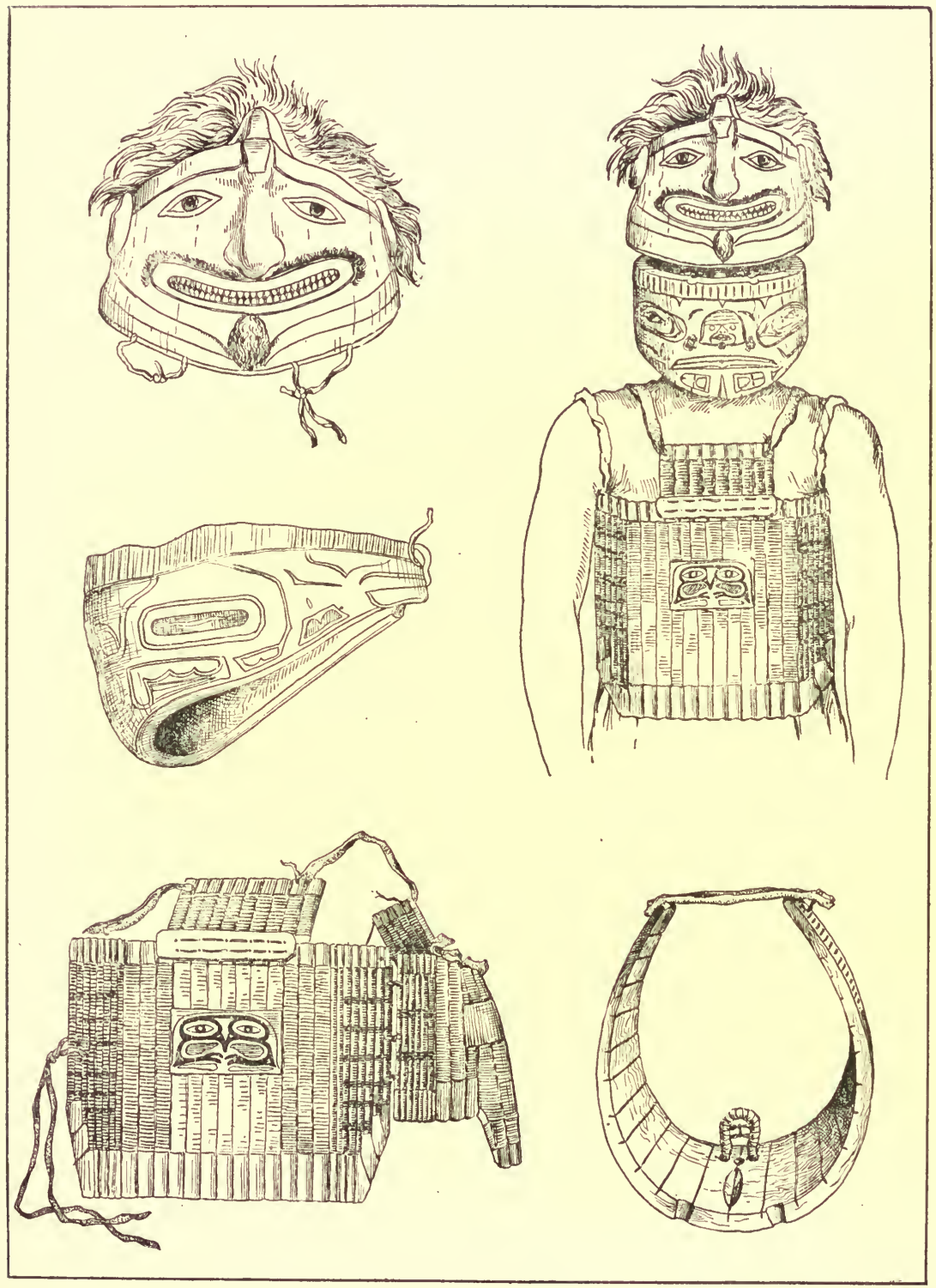

TLingit Helmets and Slat Armor. 


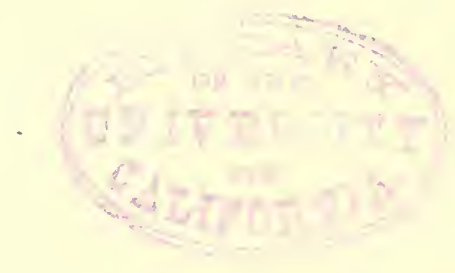


As representative of the northwestern coast culture the Tlingits and Haidas are most prominent. Captain Cook noticed that-

They incase almost the entire body in a wooden or leathern armor. They make a breast plate of wood and an arrow-proof coat of thin flexible strips bound with strings like a woman's stays. They wear helmets with curiously carved visors.*

A kind of jacket, or coat of mail, made of thin laths bound together with sinews which makes it quite flexible, thongh so close as not to admit an arrow or dart. $t$

It seems, therefore, necessary to treat the Northwest Coast as one cul. Y ture area, where the arts of the ethnic units can scarcely be ditterentiated. A close study as marked out by Niblack and shown in the care. ful collections of Lieut. G. T. Emmons, U. S. Navy, may disentangle the borrowings of the stocks of this area.

There are 4 suits of this type in the Museo Arqueologico in Madrid. 'They were collected by the Malespina Experlition of 1791. The exact locality is not stated and an account of Malespina's exploration was not publisher, as far as I can learn.

If one may judge by the Spanish names which have remained on the map, such as Malespina Island, Cape Muzon, Cordova Bay, and others, the Malespina Expedition explored the north side of Dixon Entrance and came in contact with the Haidas as well as the Tlingits. Although there is some probability of these armors being Haidan, I incline to believe them to be Tlingit.

During the course of this study, one piece of armor of unknown function in the National collection was found to be a greace, or armor for the lower leg (pl. 10). $\neq$ This unique piece discloses the hitherto unnoticed fact that the Northwest Coast warriors were more completely armed than had been imagined. This greave, learls to the inference that a similar protection was extended to the upper legs and the arms. With heavy wooden helmet, the slat coat and armor for the himbs, we have a picture of an Alaskan warrior armed cap-a-pie. In no way was this armor inferior to that employed in ancient or feudal times or at a late period among the Japanese. The resemblance of the specimen in. question to the Japanese greave is striking.

It is made up of 12 slightly tapering liard wood slats and 8 rods woven together with sinew cord. The portion not covered with weaving bears a totemic painting. When curved around the leg,

* Bancroft, op. cit. 1, p. 105.

† Cook, Capt. James, Third Voyage, Vol. II, p. 372.

$\ddagger$ Description of Plate 10.-Greave made up of 12 slightly tapering hard wood slats and 8 rods woven together with twisted sinew cord. The weaving is diversified in the central portion by carrying the threads in pairs alternately over the rods. The portion not covered with weaving bears a totemic painting. When the greave is curved around the calf of the leg, the hollowed out portions, which are also beveled, accommodate the instep and knee joint. Tied at the front with thongs. The holes along the upper edge are probably for attaching the greave to the armor for the upper leg. Length, 15 inches; width of upper edge, $17 \frac{1}{2}$ inches; width of lower edge, 16 $\frac{1}{4}$ inches. (Cat. No. 74438, U.S.N.M. Tlingit Indians, Alaska. Collected by J.J. McLean. 
the hollowed-oat portions accommodate the instep and knee joint. It was secured by thongs and probably with a band or garter. The holes along the upper edge are probably for attaching the greave to the cuissard.

Charlevoix, in speaking of the Iroquois, says:

They had even formerly a kind of mail for the arms and thighs made of the same material, ${ }^{*} i$. e., small pliable sticks pretty well wrought. $\dagger$

The resemblance between the culture of the west and east coasts of North America is striking in other instances.

W 17 Many of the figures in the Mexican codices and sculptures wear a covering around the calf of the leg, which may be the greave. In the sculptures from Yucatan this greave or legging seems to be of horizontal bands and square plates.

The rod type of armor of the western area is well represented by specimeus in the National Museum. All the examples extant range from Sitka to northern California in a region comparatively lately explored.

The rod and slat types are mixed; in the method of twining together the elements they are identical. In some localities the broad band of rods is alone found, while among the Tlingits, or around Sitka, occur rod armor, slat armor, and a combination of both types in the same piece, as well as skin armor.

In form the Aleut armor, instead of following the Eskimo type, belongs with the rod type of the Indians. The perforation of the rods, however, and the method of lashing, show Eskimo handiwork. D'Orbigny says: "Les armes défensives consistaient en une cotte de jones tressés qui leur couvrait tout le corps." $\ddagger$

Dr. W. H. Dall, during his exploration of the caves of the Aleutian Islands, found the armor figured in pls. 11 and 12.ई "Under the

* Charlevoix, F. X. de, Vol. I, p. 338, Lond., 1761.

† Id., Letters to the Duchess of Lesdiguiéres, p. 143, Lond., 1763.

$\ddagger$ D’Orbigny, Voyages, p. 579 .

\section{@DESCRiption OF PLATES 11 AND 12.}

Plate 11, rod armar.-Made up of two series of cedar rods, one-half inch in diameter and different lengths, painted red. The lower series containing 68 rods; the upper series, two side sections of 10 rods and a curved piece each, and a central section containing 22 rods with curved side pieces. The rods are perforated through either eud and held in series by a sewing of finely plaited sinew cord, the cord being brought through the hole in the first rod, leaving two long ends. These are brought past each other from opposite sides through the hole in the next rod, anil so forth. The sections are joined by a riekrack lashing, engaging with the horizontal sewing. The rods are perforated from side to side and a thin rod of whalebone drawn through, rendering the armor flexible. At the lower and upper edges of the armor the ends of the rods are chamfered. There are two wooden toggles on the right side.

Plate 12, rod armor.-Same coat as shown in pl. 11, doubled together, showing the position upon the body in wearing the armor. This view shows also a portion of the inner side and the projeeting ends of the whalebone binding strip which has been broken. Width, 40 inches; height, 25 inches. (Cat. No. 17249, U.S.N.M. From a burial cave in thu Island of Amaknak. Collected by E. Hennig.) 


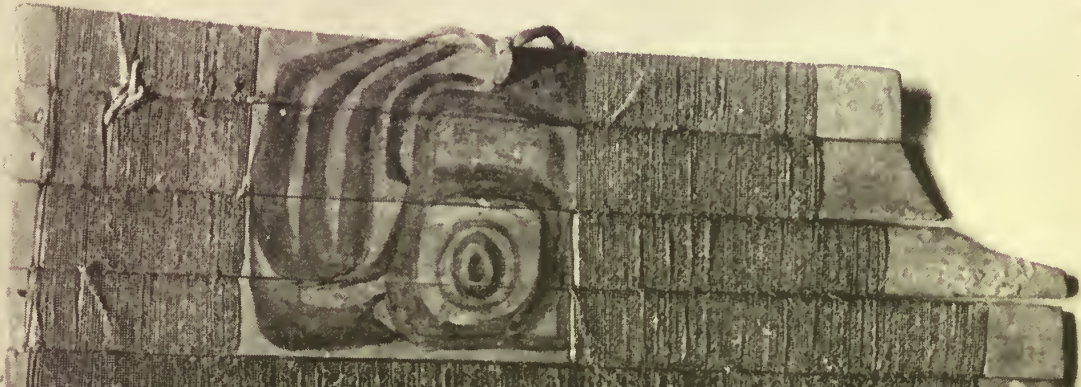

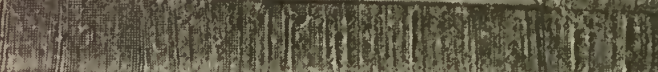

ff
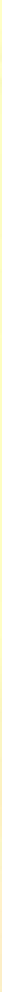
) 


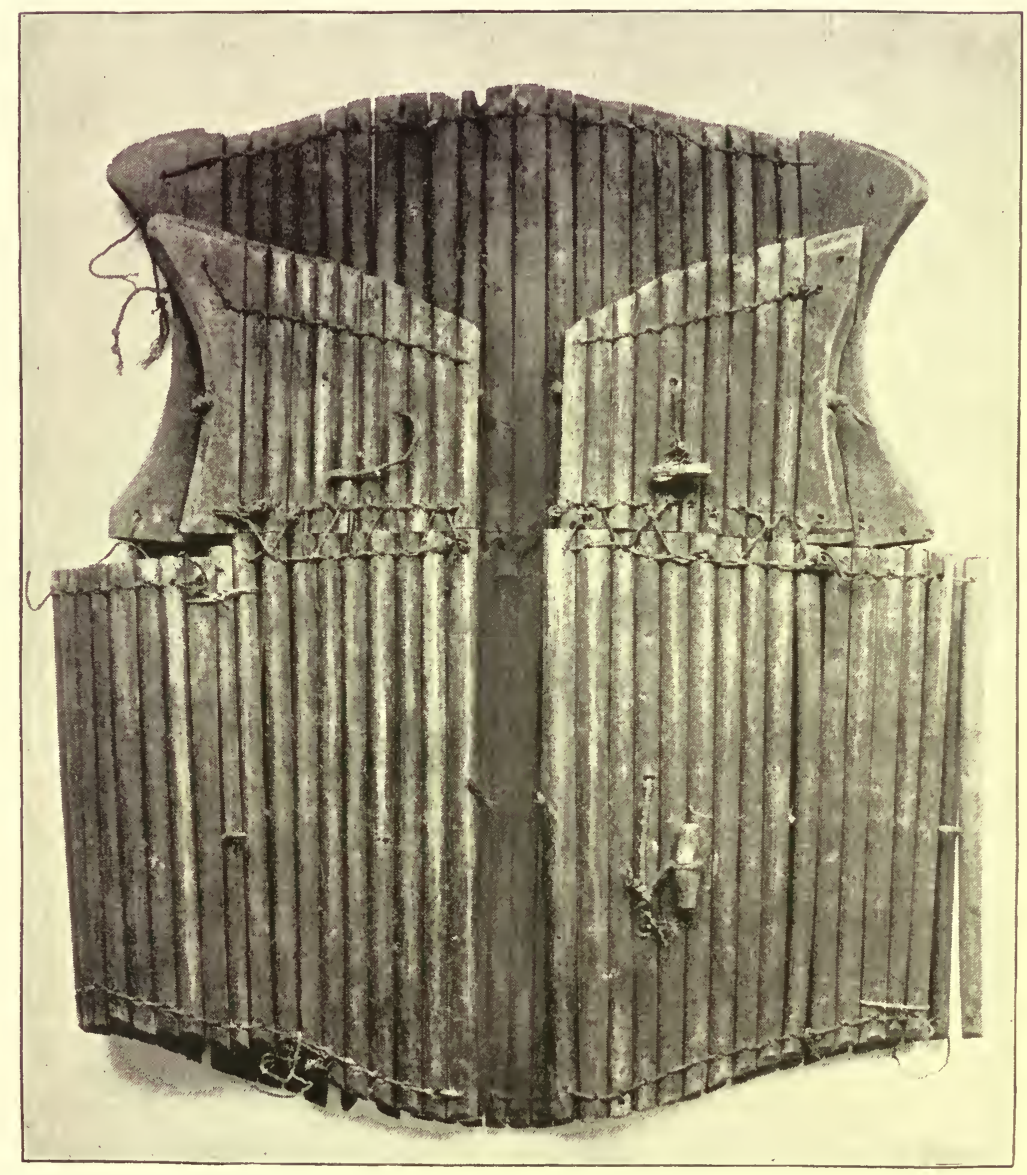

Prehistoric Aleutian Rod Armor.

Cat. No. 17249, U. S. N. M. 


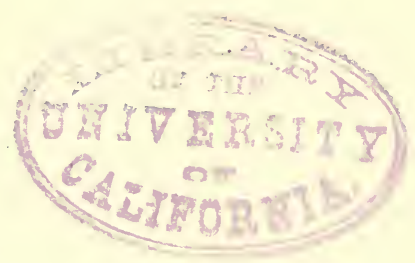




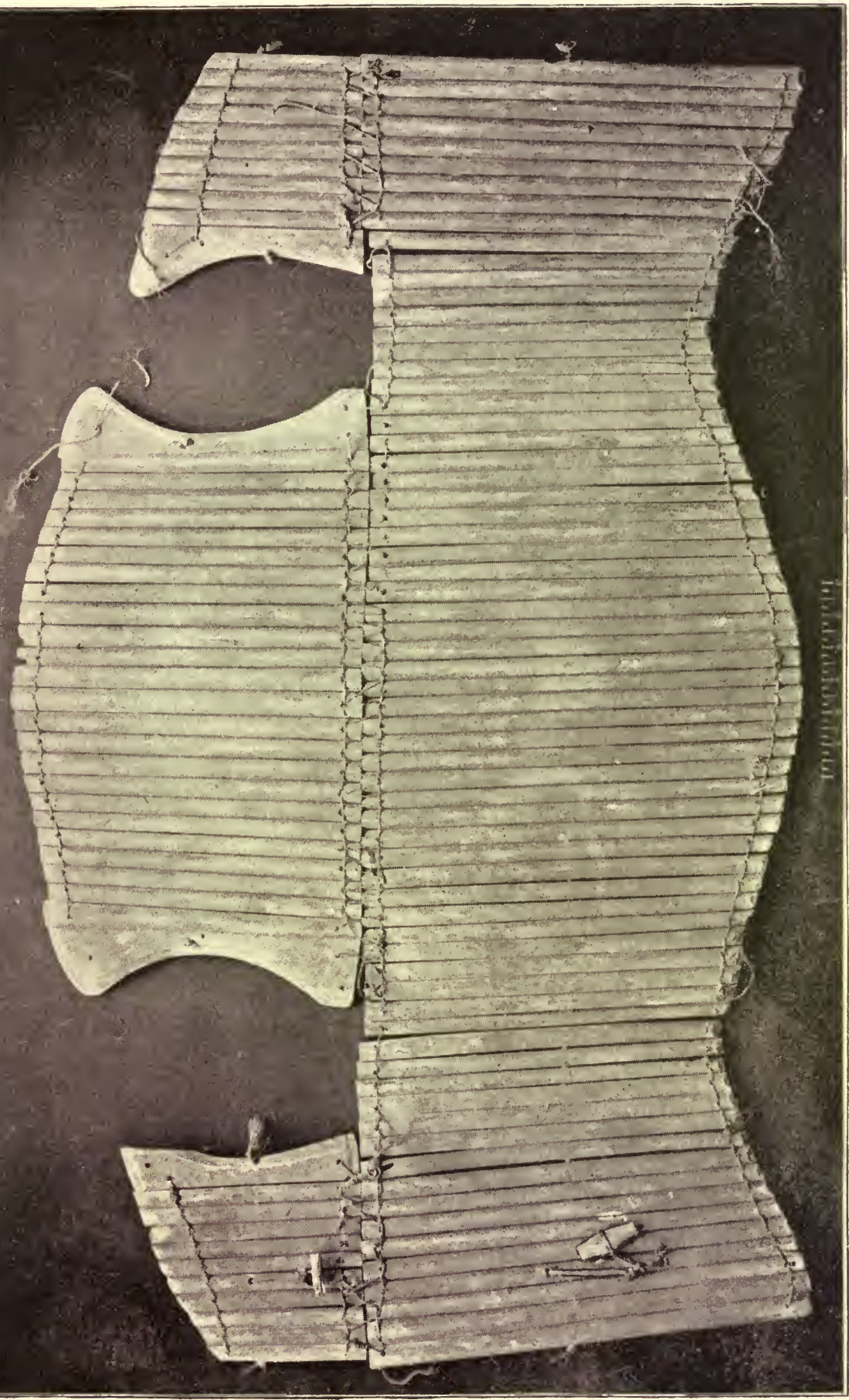



net was inserted a piece of wooden body armor (17249) composed of small, round rods of proper size, united by sinew cords and with nicely carved wooden pieces about the armholes. This is the only piece of this aboriginal armor known to be in existence. It was fastened behind with two loops of sinew, into which wooden buttons were inserted. The small rods of which it is composed were about three-fourths of an inch in diameter, painted red.

"The armor, slight as it was, must have been a tolerably good pro. tection against the bone and stone arrowheads of the natives." *

In the northern portion of this area, except in the Aleutian Islands,

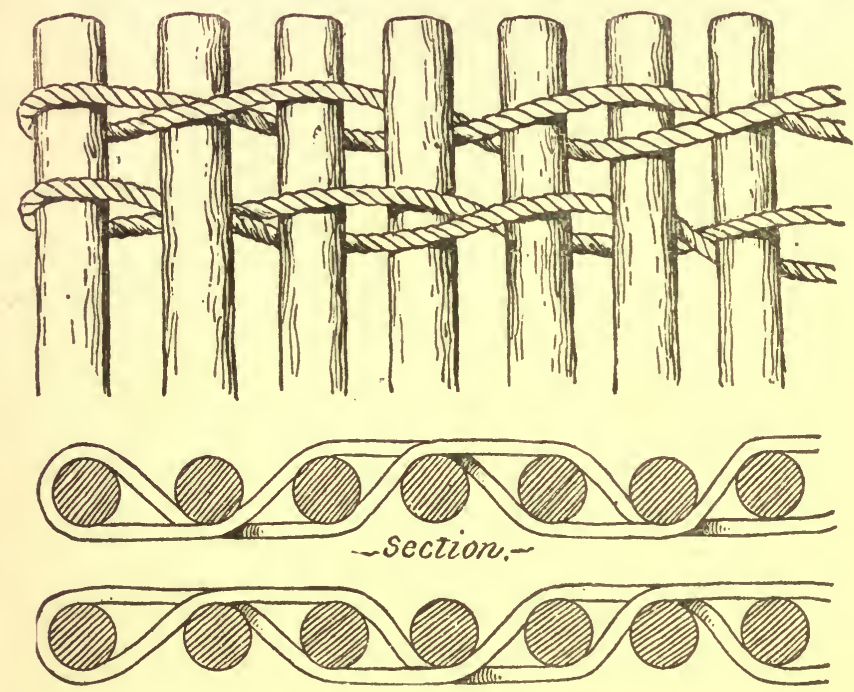

Fig. 4.

SHOWING DETALl OF WEAVING ROD AND SLAT ARMOR OF THE NORTHWEST COAST.

the rod armor is an oblong band composed of peeled rods of uniform length and diameter held in series by bands of weaving (pl.13). $\dagger$

Lieut. Niblack says, in describing this armor, that-

The threads are sometimes single and sometimes in pairs, and are made to pass over and under the rods in pairs, but in such manner that the overlappings alternate from one row to the next. This is shown in detail in fig. 4, where $1 a$ and

${ }^{*}$ Dall, W. H., Remains of Later Prehistoric Man in the Caves of the Aleutian Islands, p. 18, Smithsonian Contrib. to Knowledge, No. 318.

† DESCRIPTION OF PLATE 13.

Rod armor.-Composed of 72 peeled rods of nniform length and diameter, held in vertical series by alternate bands of weaving of woolen and sinew cord. The rods are bunched in the middle of the band. The ends of the rods are neatly hollower out, forming cup cavities, and there are 4 equidistant vertical bands of red paint. This band was probably worn with a skin coat, both specimens having been secured from the same native. There appears to be no device to prevent the rod band slipping down. Width, 30 inches; height, $23 \frac{1}{2}$ inches. (Cat. No. 168158, U.S.N.M. Taku Indians, southeastern Alaska. Collected by Herbert G. Ogden.) 
$1 b$ represent the part of one cord, and $2 a$ and $2 b$ represent those of another. The view represents the upper left-hand corner of the weaving and two upper threads, showing 7 rods in both plan and section. As stated, this method of running the cords or twine is varied by occasionally running them in pairs. *

Bands of rods of this character are intended to be worn under or over the skin armor, encircling the body below the armpits, and there are no shoulder straps to prevent the armor slipping down over the hips.

To the southward the rod band assumes a more effective form. It is cut out for the arms and has shoulder straps. Just where this form begins it is not possible to say with exactness, probably with the Tinné. The specimens are from the Shastas, Hupas, and Klamaths of Oregon and California (pls. 14 and 15). $\dagger$

The following references may be of interest:

Western Tinné: "While on the warpath they also wore a kind of armor or cuirass consisting of dried sticks of the same kind of wood, Amelanchier alnifolia, arranged in parallel order and kept together with babiche lines interlaced in several places. $\neq$

The Chinooks wear "a kind of vest, made of small round sticks of the size and shape of arrows 12 inches long; they are laid side by side, and then sewed together and fixerl on the body like a waistcoat."§

* The Inclians of the Northwest Coast, Niblack, A. P. Report of Smithsonian Inst., Part 11, 1888, p. 269.

† DESCRIPTION OF PLATES 14 AND 15.

Plate 14, rod armor.-Made of 74 strips of wood formed by splitting branches, woven with native cord of wild hemp. The checkered portion in black is woven with cord made of human hair. Short rods are worked in below the armpits. All the rods are split at either end, the finishing cords drawn into the split to secure the weaving. In addition the armor is bound on the upper and lower edges with skin sewed with sinew. The shoulder straps are of otter (q) fur. The surface of the armor shows 4 horizontal bands of red paint. Width, 38 inches; height, 30 inches. (Cat. No. 2928, U. S. N. M. Shasta Indians. northern California and Oregon. Collected by Lieut. G. T. Emmons, U. S. N.)

Plate 15, fig. 1, rod armor (Klnig-klicyst-e-cue-it-wul).-Made of 118 peeled rods, woven together with native twiue, bound with buckskin on upper and lower edges and armholes. Shoulder straps of leather; 6 horizontal stripes of red cord cross the front of the coat. "It is tied across the breast from left to right. The red lines denote the number of enemies slain or captives taken; also the rank of the wearer. This class of armor was in common use among the Natanos and Kennucks before the introduction of firearms, but it is now obsolete, nearly. This is the only complete suit that Lieut. Ray conld obtain." (The Ray Collection, Smithson. Rept., 1886, 1, p. 230.) Width, 41 inches; height, 21 inches. (Cat. No. 126909, U. S. N. M. Huap Indians, California. Collected by Capt. P. H. Ray, U. S. A.)

Plate 15, fig. 2, rod armor (Tal-luck).--Modern. Made up of 44 oval rods of pins wood. The cord is of native hemp and cords made from sisal, the latter probably derived from ropes. The weaving is diversified by using cords colored red and yellow; bound with buckskin painted red; shoulder straps of buckskin; tying straps at the sides. Width, 38 inches; height, 21 inches. (Cat. No. 2094, U. S. N. M. Klamath Inclians, Oregon. Collected by L. S. Dyar.)

$\ddagger$ Morice, A. G., the Western Dénés. Proc. Canıı. Inst., Vol. xxv, 1889, p. 140.

$\oint$ Ross, Alexander, adventures, etc., on the Oregon and Columbia rivers, Lond., 1849, p. 89. 


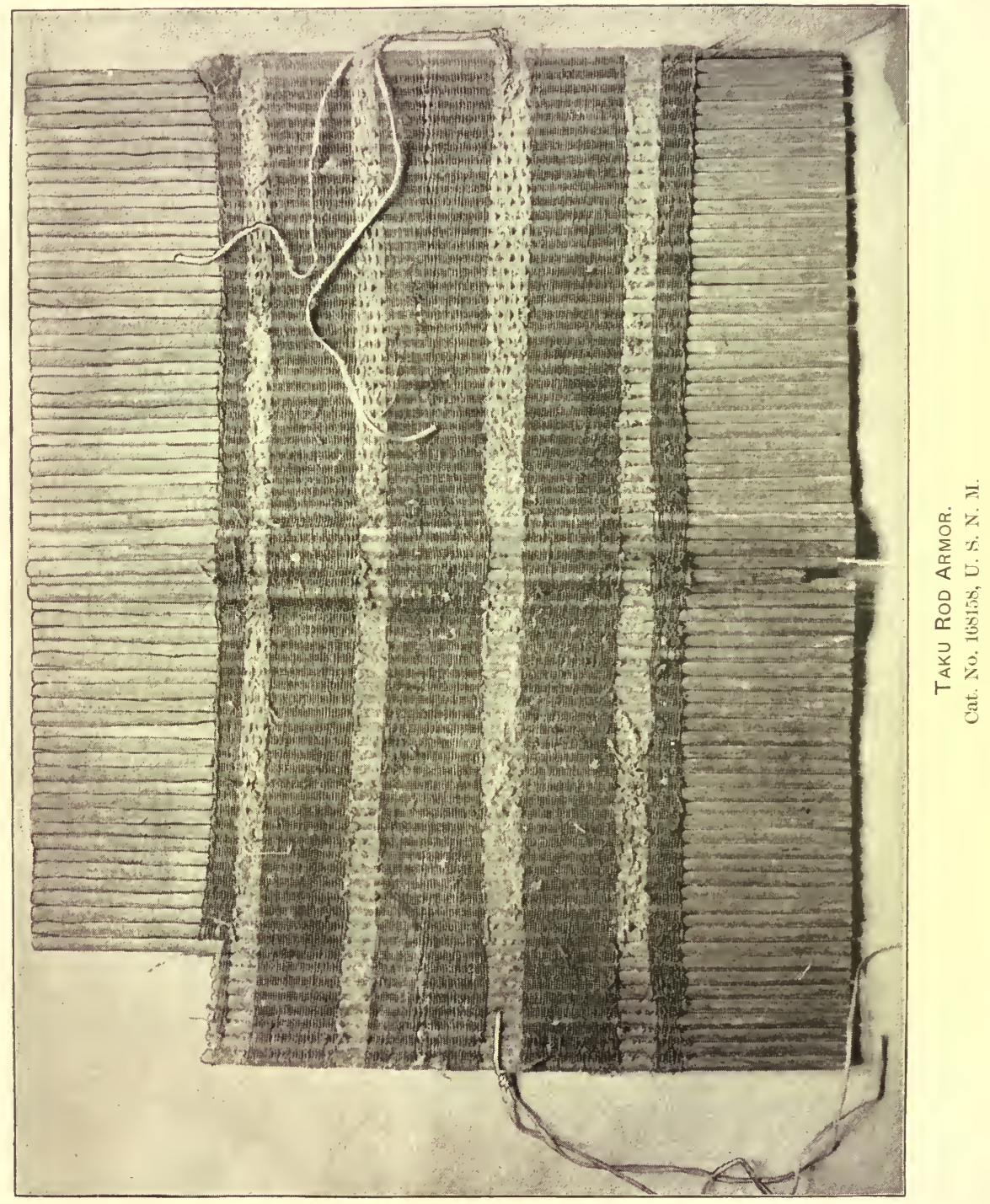




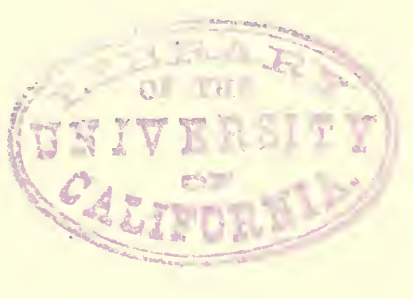




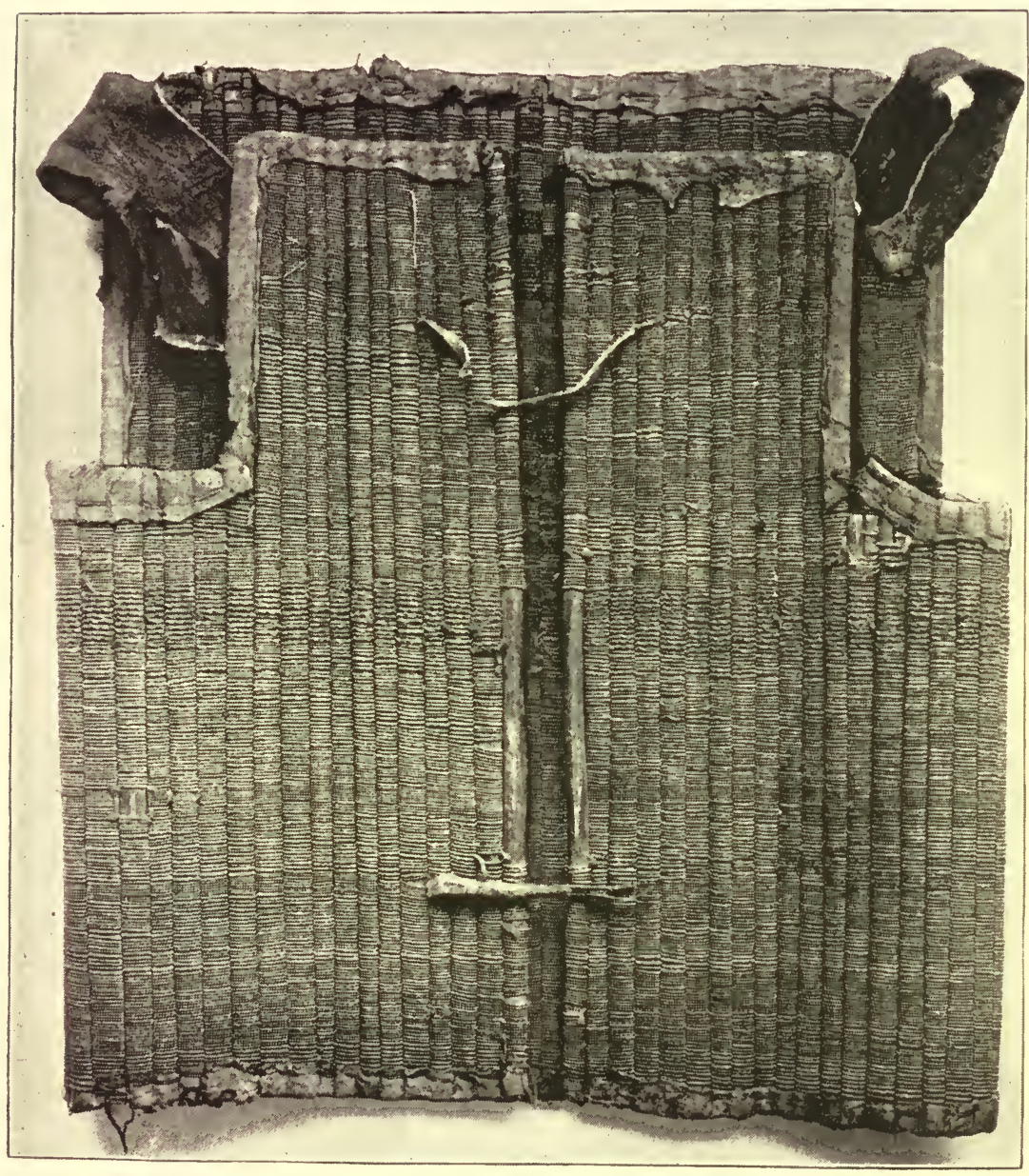

SHASta ROd CoAT.

Cat. No. 2928, U. S. ז. M. 


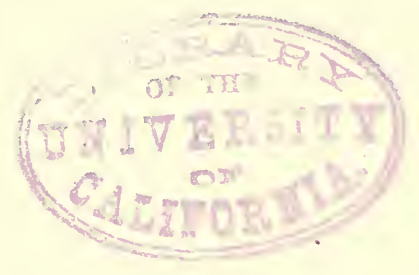




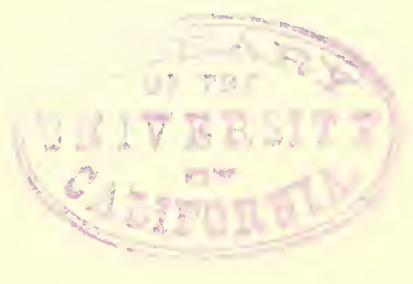


Among the Hupas "there is another kind of armor made of wattles and twine, woven and bound with buckskin. This is worn in battle to protect the body; it is tied across the breast from left to right. The red lines denote the number of enemies slain or captives taken; also the rank of the wearer. This class of armor was in common use among the Natano and Kenuck Indians before the introduction of firearms, but it is now nearly obsolete." *

- The rod coats were put on like a vest and were tied in front. The rear portion, being a little longer, protected the back of the neck.

On the western slopes of the Rocky Mountains and on the Great Plains the natural defensive protection of the great land and sea mammals, transferred by man to his own body, becomes, in turn, his efficient armor.

The skins of the elk and moose on the northwest coast and the bison in the interior to the south furnish excellent material for defensive clothing. These skins are invariably tanned to render them flexible, and are often coated with glue and sand over certain portions.

Father Morice, in his clear description of the process, says:

Another sort of armor, indigenous to the Déné nation, was the peoesta (wherein one sits). This had the form of -a sleeveless tunic falling to the knees, so that it afforded protection to the whole body save the head-in hard fights the Dénés invariably shot kneeling. The armor or enirass was of moose skin, which, when sewed according to the proper pattern, was soaked in water, then repeatedly rubbed on the sandy shores of a stream or take and dried with the sand and small pebbles adhering thereto, after which it was thoroughly coated with a species of very tenacious glue, the principal ingredient of which was boiled isinglass, obtained from the sturereon. Being again, before drying, subjected to a thorough rubbing over sand, it received a new soating of the aforesaid glue. When this process had been repeated three or four times, it formed an armor perfectly invulnerable to arrows over the parts which were thus protected. $t$

The skin coats were always inade in one piece folded over, sewed above the shoulders, leavingan orifice for the head and with a hole cut out of the left side for the left arm, the right side of the garment remaining open. The skin was often donbled, but more frequently the coat was reinforced with pieces of thick hide. "Sometimes shoulder guards were added.

It will be seen that the leather coats from Sitka are short and follow the type of slat armor. This will be noticed in the "swallowtail" for the protection of the pubic region, or which assumes this shape by the cuttming away of portions of the skirt over the groins (pls. 16 and 17). Sometimes a slash was made over the thigh and in front of the throat.

* Mason, O. T., The Ray Collection, Rep. Smithsorrian Institntion, 1886, p. 230. † Morice, A. G., The Western Dénés, Proc. Canad. Inst., Vol. xxv (Oct., 1889), p. 140.

$\ddagger$ DESCRIPTION OF PLATES 16 AND 17 .

Plate 16, Fig 1, skin armor.-Made of two thicknesses of caribou hide, scarfed rregularly to secure flexibility. Sewed around the border with rawhide. Padded in the truncated portion with heavy pieces of hide. The garment has been patched at the edges eaten away by rats. Formerly worn as an undergarment for protection against daggers, spears, and arrows. Outside was worn a rod band as a further protection. This specimen is rery ancient and primitive, worn before the introduction

H. Mis. 184 , pt. 2 $-41$ 
The shoulder guards were worked out of the hide at the left armhole, or added over one or both shoulders. On the front are one or two loops of buckskin, probably for the attachment of the bow and quiver or dagger.

On the right side the armor was usually fringed, and in some cases a band of lighter skin was sewed along the same side. This band was often decorated.

To the southward the coat seems to become longer and simpler in ontline (pls. 18, 19). *

of fire arms. Width, 21 inches; length, 28 inches. (Cat. No. 130587, U.S.N.M. Tlingit Indians, Alaska. Lent by Max B. Richardson.)

Fig 2, skin armor.--Made of tanned hide; two thicknesses; sewed along the upper edge. The "swallowtail" portion is reinforced with two extra thicknesses, making four in all. The coat is very heavy. The sewing is done with sinew. Width, 25 inches; height, 33 inches. (Cat. No.60239, U.S.N.M. Tlingit Indians, Alaska. Collected by J. J. McLean.)

Plate 17, skin armor.-Made of one piece of heavy elk skin apparently smoketanned, lined iuside with another piece sewed around the lower portion. Ample cuts for arm holes. Over the left shoulder is fastened an epauliere, made of a heavy piece of folded hide. For convenience in putting on or off the armor, the band over the right shoulder is buttoned over a wooden toggle. Fastened with thongs on the right side. Two loops in front are probably for the bow. Width, 201 inches; height, 29 inches. (Cat. No. 60240, U.S.N.M. Tlingit Indians, Alaska. Collected by J. J. McLean.)

* Description OF Plates 18 AND 19.

Plate 18, Fig. 1, skin armor.-Front view. Made of very heavy hide, with corrugated appearance, single thickness. A strip of lighter leather, cut from a painted garment, has been sewed to the left sirle. A double shoulder protector has been sewed to the left side of the neck opening, and the skin has been cut and enlarged by gussets to protect theright shoulder. A slit cut in the skirt of the coat admits of free movement of the knee. The fringe is wrapped with strips of grass, tied, by thongs, on the left side.

Fig. 2, skin armor.-Rear view of armor. Curiously, this armor must have been worn by a left-handed man, as it is put on in the reverse of the other coats described. Widtl, 30 inches; height, $37 \frac{1}{2}$ inches. (Cat. No. 130588, U.S.N.M. Alaska. Lent by Max B. Richardson.)

Plate 19, Fig. 1, skin armor.-Made of tanned caribou skin folded in the usual way and reinforced. Fringed on the right side. The coat is longer than those worn to the North. The leather has apparently been stiffened with glue. The feature of this coat is that two very heavy pieces of hide go over the shoulders and form a slit in front of the neck. The buckskin loops in front are for the attachment of the quiver. Width, 32 inches; lieight, 37 inches. (Cat. No. 46164, U.S.N.M. Chileat Indians, Alaska. Collected by Dr. T. H. Bean.)

Fig. 2, skin armor.-Made of thick tanned elk or moose skin folded twice into oblong form like a sheet of note paper. Sewed over the shoulders and strengthened inside by hinge pieces. Open along right side the edges cut into coarse fringe. A short slit down left side below the shoulder leaves a passage for the left arm. About miclway near the right side is fastened a wooden toggle, by which, probably, was suspended the dagger. The front of the coat is discolored and dented as though an attempt had been made to render the leather more dense by hammering. The leather has perhaps also been treated with glue, as described by Father Morice among the Tinne. Inside the armor at the back is a finely drawn and painted totem : circle $10 \frac{1}{2}$ inches in diameter. Width, 26 inches; height, 36 inches. (Cat. No. 168 U.S.N.M. Taku Indians, Sontheastern Alaska. Collected by Harbert G. Ogricr. 


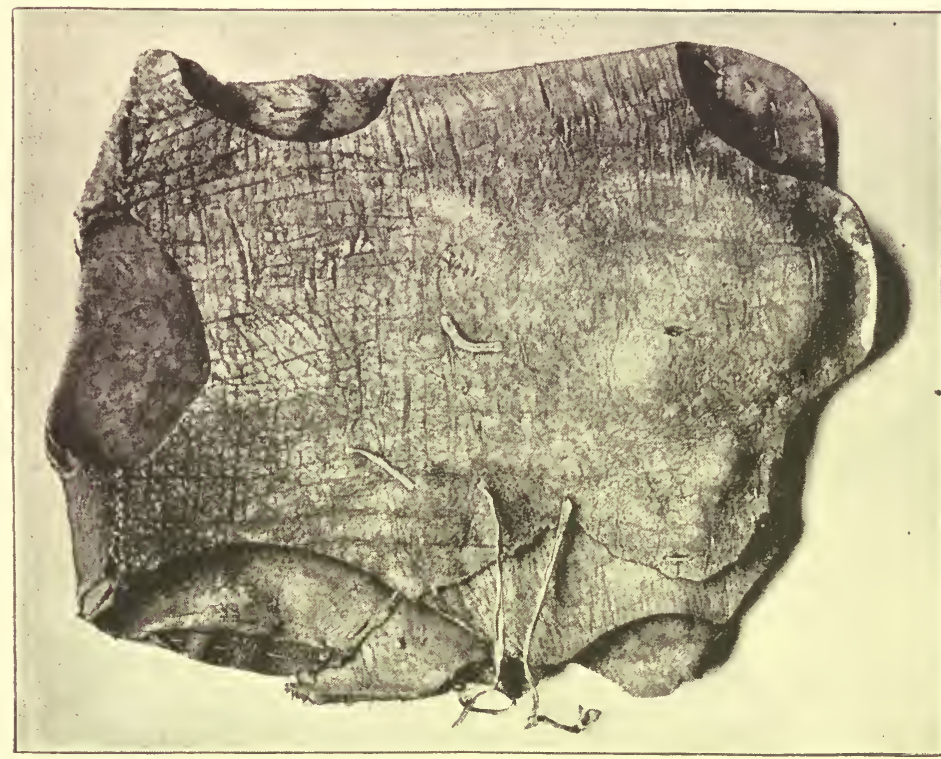

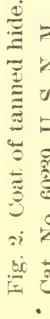

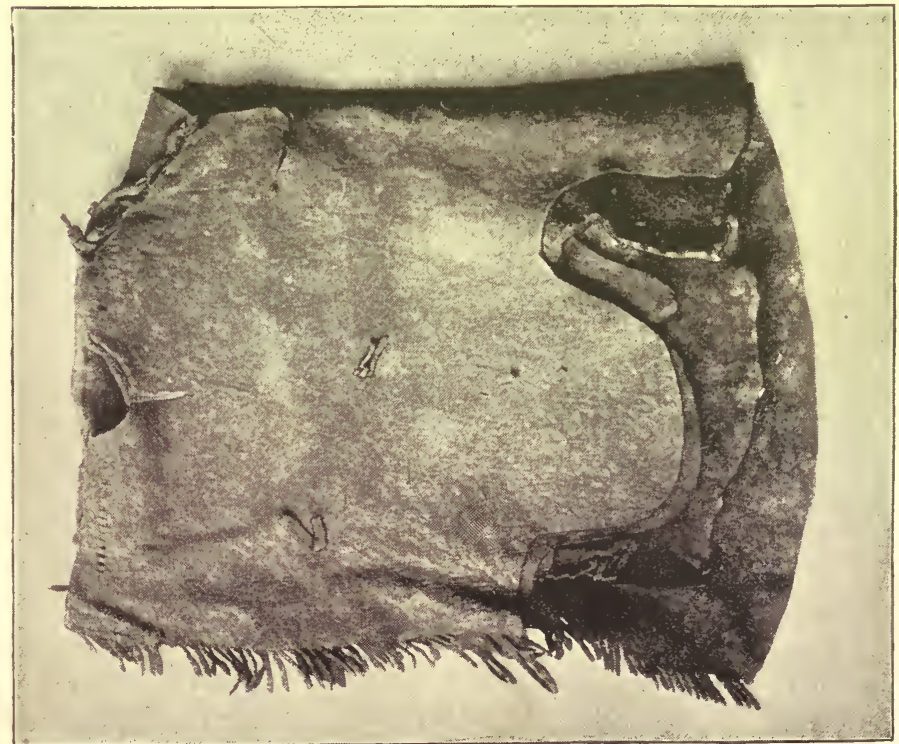

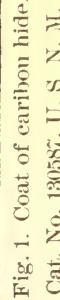





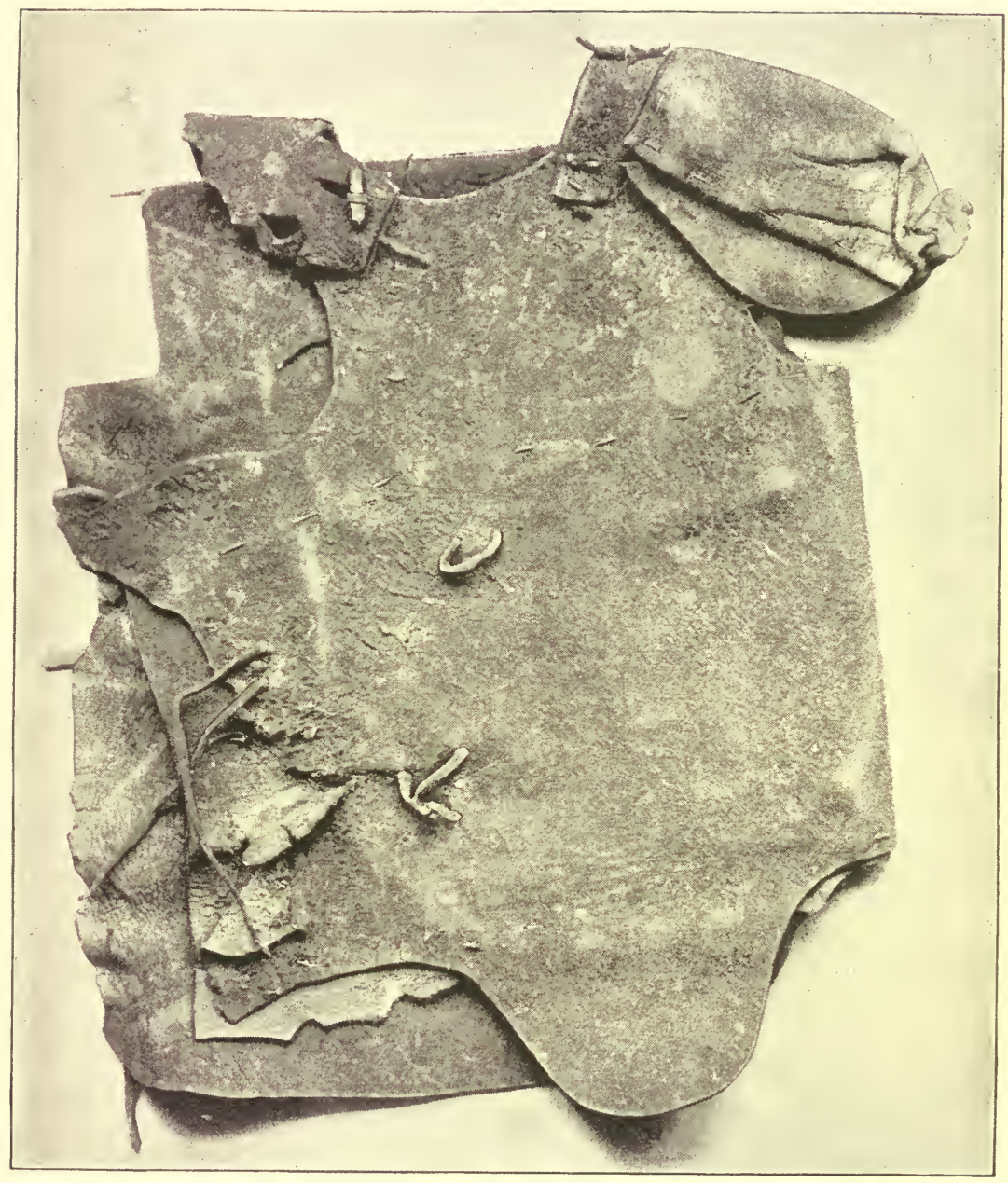

ALASKan SKIN ARMOR WITH SHOULdER Gyards.

Cat. No. 60240 , U. S. N. iI. 
r.

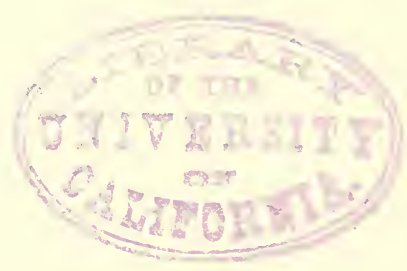



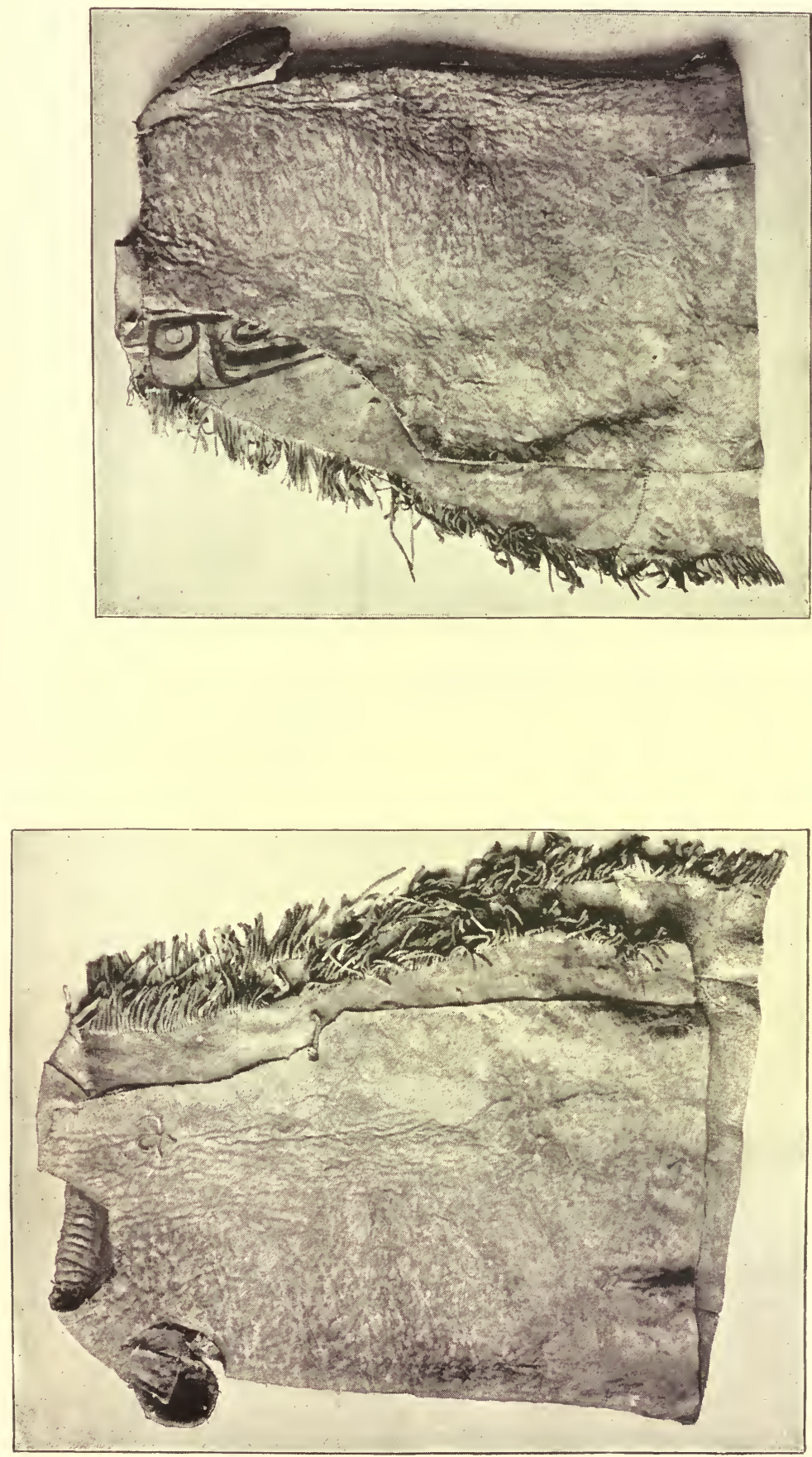

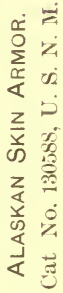


'

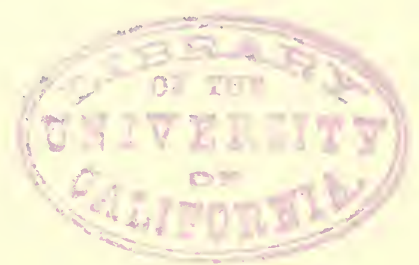




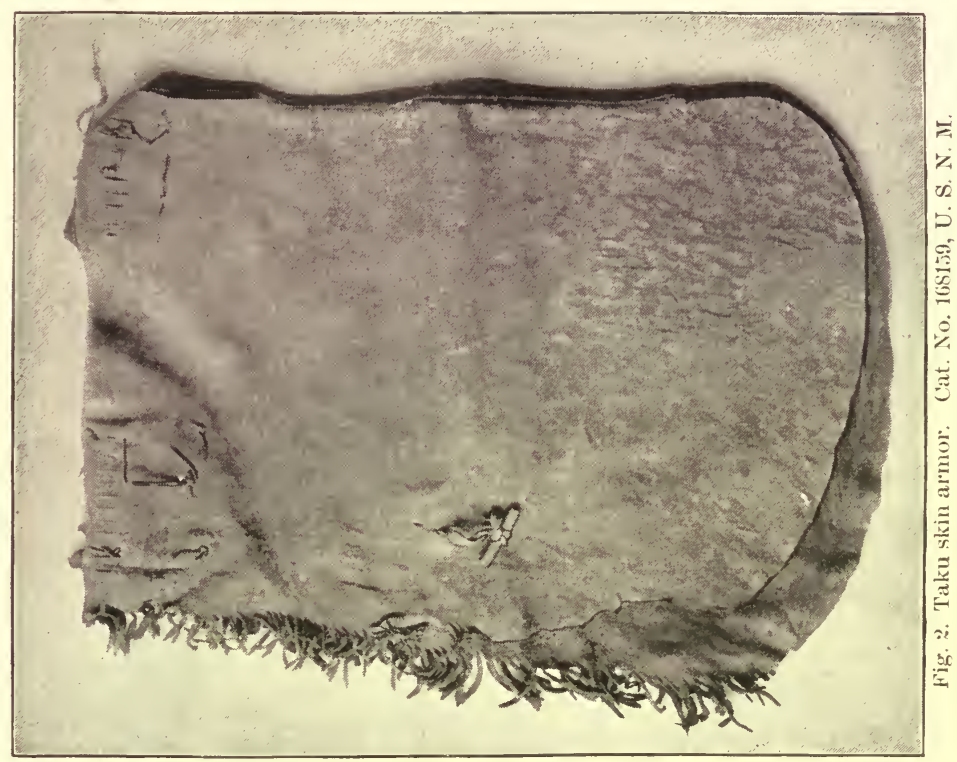

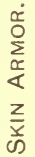

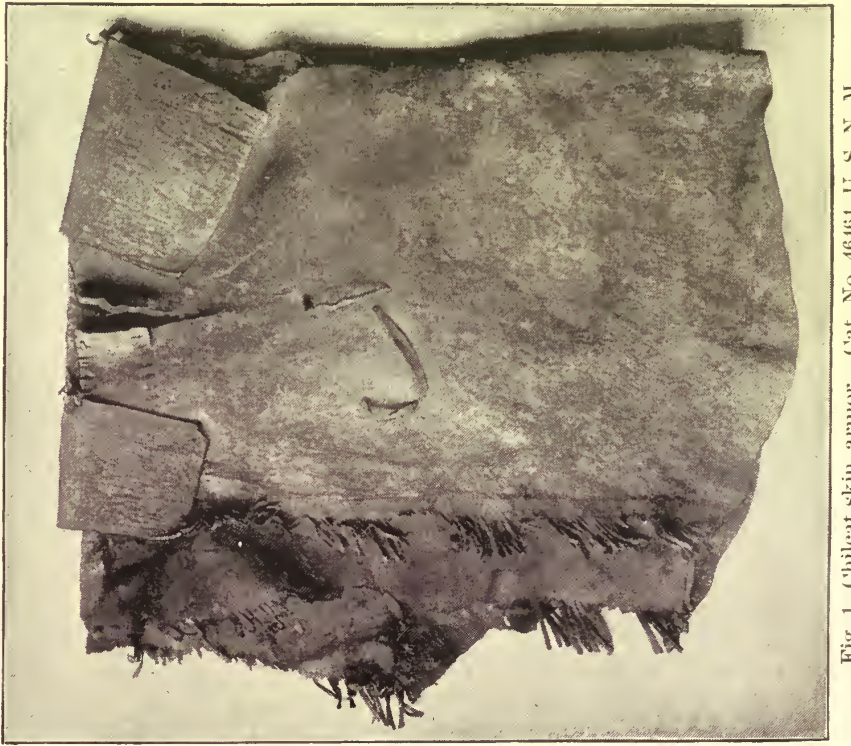



The long coat culminates among the Hupas and Klamaths, although $\chi$ some Alaskan tribes wore long coats identical with the ceremonial coats (pl. 20)** B.

Two modern armors from Sitka, in form of a waistcoat, are curious. Both open in front and are fastened by lappets and brass buttons of English mannfacture. One is plated over the entire front and a portion of the back with Chinese coins, like the penny armor of Europe; the other is plain. The derivation of these coins is not known, but the collector supposes the work to be that of Chukchis. These are current Chinese coins like those brought to this country by the Chinese to be used in gambling. There are a few Japanese coins on this coat. The armor was collected in 1870 (pl. 21). $\dagger_{\text {。 }}$

Decoration of the war armor was infrequent. The fringe has been mentionerl. Applied bands of quill work on leather fringe have been observed. The slat armor often bore totemic devices, and the rod armor was diversified by bands of weaving of different colored cords or by painted bands. In the interior of two coats from southern Alaska (Takus and Tlingits) are elaborate colored totemic paintings. Since the painting is not seen, it can not be for ornament. Perhaps it is a fetichistic protection.

Two very heavy, long, wide skin coats from the Northwest Coast in

* Description of plate 20.

Skin armor (Cue it wul).-Made of a large elk skin, tanned, folded on itself. The outer portion falls as a skirt to the ankles, while the inner portion reaches only to the knees, and the hard neck portion of the hide comes in front and acts as a plastron to protect the belly and thighs. Joined over the shoulders by leather straps worked through-a series of slashes. Zigzag eut for the left arm. Fringed at the side and tying thongs on the right. The front and back decorated with eusps, dots, circles, and lines in red and blue paint. It is worn so as to cover the left side, with the left arm through the slit, the head through the opening. The suit has been worn by several geuerations and in some of the modern battles with the whites, in which the bullet marks were received. There are also arrow cuts which were received in battle. The cusps and triangular figures are intended to denote the number of enemies slain and captives taken. (See. "The Ray Collection," Report of the Smitl. sonian Institution, 1886, 1, p. 205.) Width, 26 inches; height, 47 inches (Cat. No. 126908, U.S.N.M. Hupa Indians, California. Collected by Capt. P. H. Ray, U. S. A.)

† DESCRIPTION OF PIAATE 21.

Fig. 1, skin armor.-Made of three layers of tanned hide, hardened. Two layers are formed by folding and the third is inserted between them. In general shape it is that of a waistcoat, with collar sewed on with thongs, but not formed of pieces like the similar armor. Fastened in front with 4 lappets and. sailors' buttons of brass. On the right side is a loop of buckskin, probably for the dagger. Height, 23 inches. (Cat. No. 18927, U.S.N.M, Sitka, Alaska. Collected by James G. Swan.) Fig. 2, skin armor.-Made of thick tanned hide in imitation of an old-fashioned waistcoat, the resemblance being exact in particulars of cut and sewing. Plated over the front and shoulder of the back with Chiuese coins sewed on with sinew cord. Four lappets for fastening in front with brass buttons of English manufac-

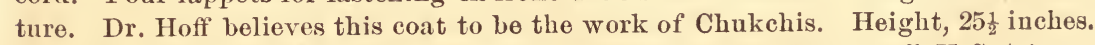
(Cat. No. 9284, U.S.N.M. Sitka, Alaska. Collected by Dr. A. H. Hoff, U. S. A.) 
the national collection are of problematic purpose. They were sent in as armor by the collector, and from the thickness, weight, and other points are evidently defensive. There is, however, no armhole on the left side nor projection for the shoulder. In one suit the neck opening

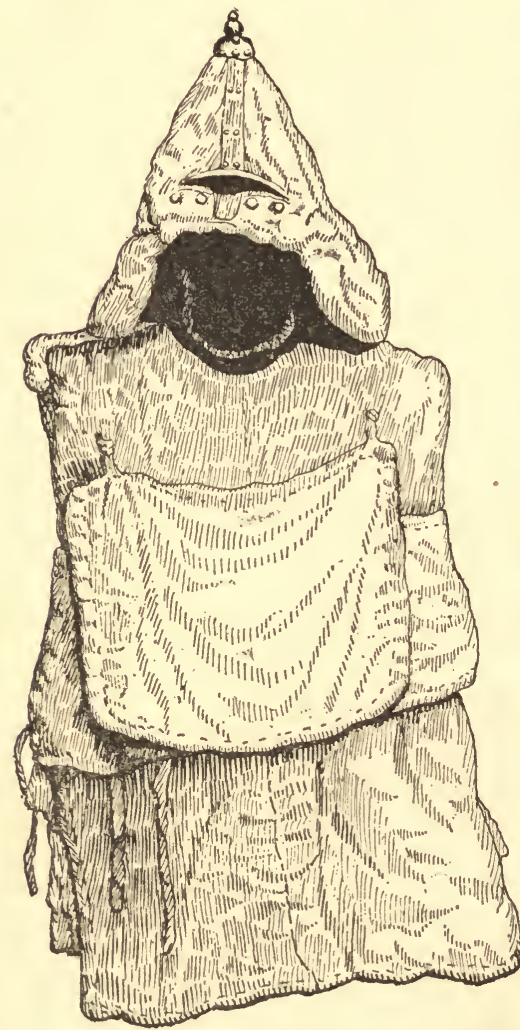

Fig. 5.

ANCIENT KOREAN COTTON ARMOR.

Cat. No. 128344, U.S.N.M. Korea. Deposited by Dr. G. Brown Goode.

is large and is surrounded with a leather-covered collar made of short wooden slats, slightly interlocking, held together with a cord twining. In the other suit the collar is of hide (pl. 22).*

If these objects are defensive they could scarcely be used by a man on all fours for stalking, as they are too wide and long, and the arms would be completely hampered. They would be most useful as armor for some animal. While one triberat least (the Shoshones of the Upper Missouri) is known to have protected their horses with armor, $\dagger$ the North. west Coast tribes did not have horses. A further suggestion is that they were ceremonial.

These objects are noticed here with the view of ascertaining their function.

Padded armor, which was used in Mexico and Central America, is the remaining type. No specimens of Mexican padded armor are extant. In some of the sculptures quilted armor is perhaps represented by a groundwork of small squares. A search of the codices and an examination of the sculptures will doubtless throw much light upon this subject.

* description of plate 22.

Fig 1, skin robe.-Of hide, ronghly curried in tanning. The collar is a slight cut on the left side which does not penetrate the inner fold. A painted, fringed band has been neatly sewn to the right side. On the inside is an elaborate totemic painting. Length, 52 inches; width, 36 inches. Northwest coast.

Fig 2, skin robe.-Made of a large tanned elk, or caribon, hide, doubled, the short fold being insicle. A collar composed of short interlocking slats. of wood, woven together with cord in the manner of the slat armor and covered with leather, is sewed to the neck. Fringed at the sides. Four bands of fringed buckskin decorated with colored grass are sewed on one side. Length, 54 inches; width, 32 inches. (Cat. No. 74440, U.S.N.M. Alaska. Collected by J.J. MeLean.)

t See page 646. 


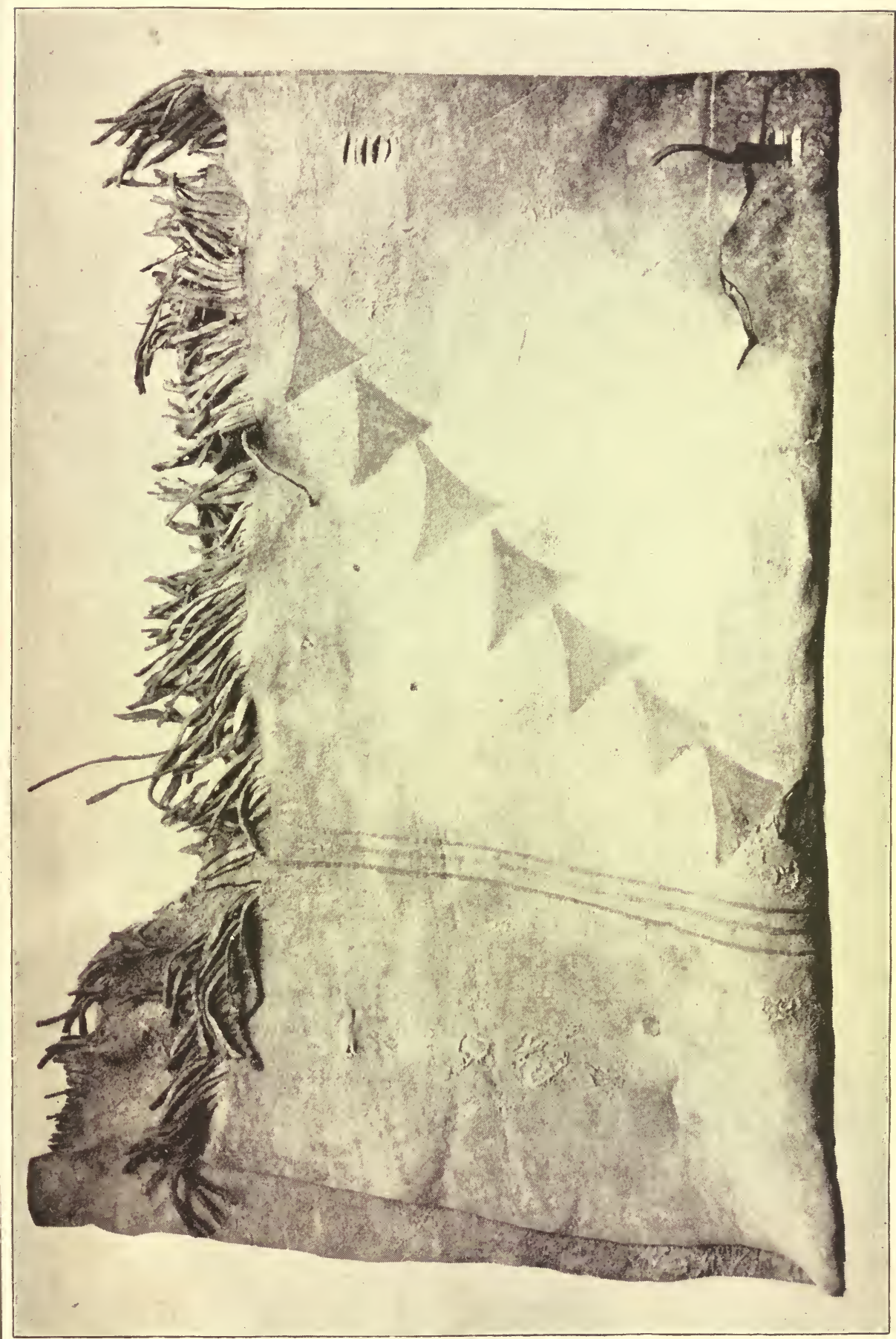

HUPA ELK-SKIN ARMOR.

Cat. No. 126908 , U. S. N. M. 


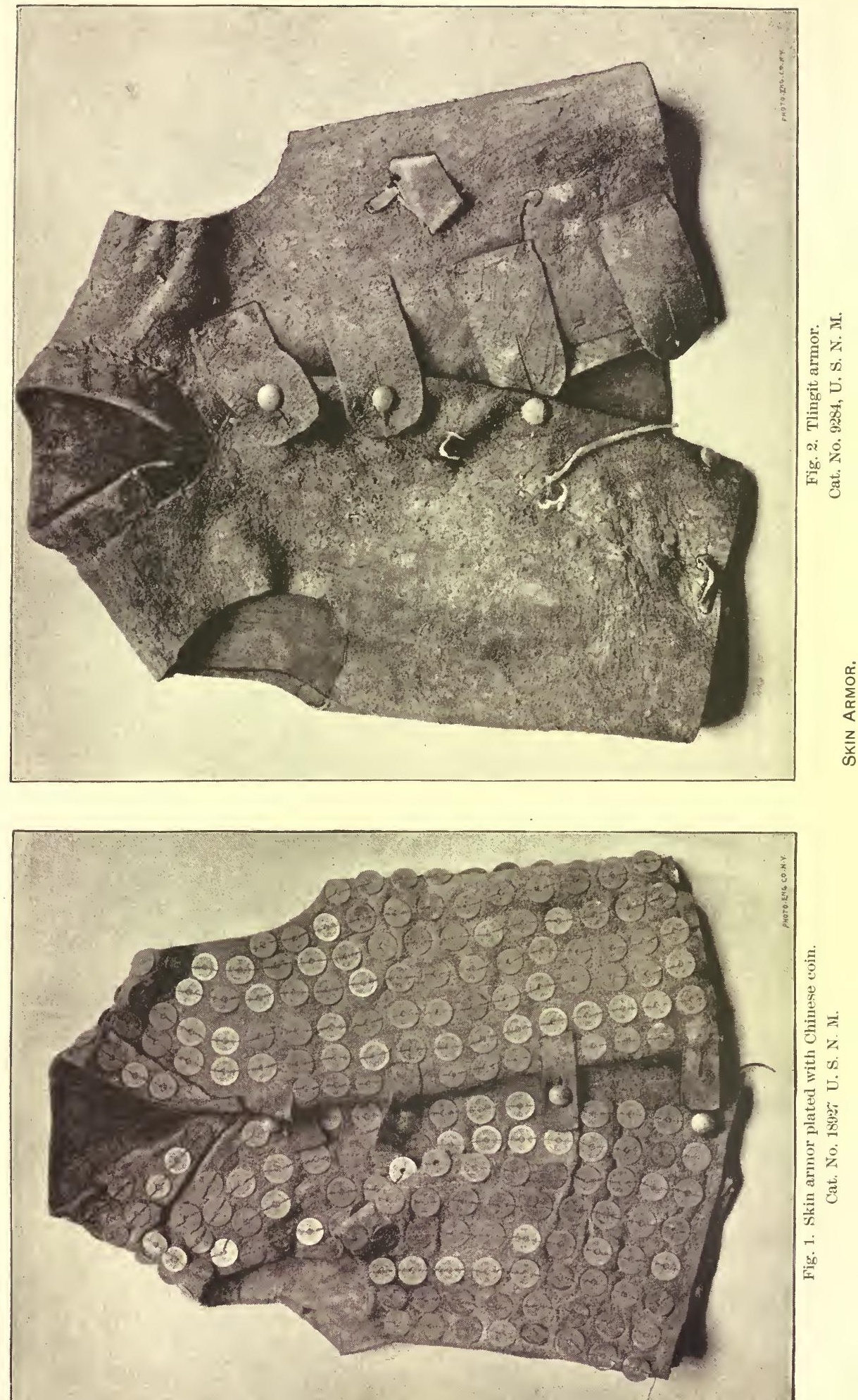



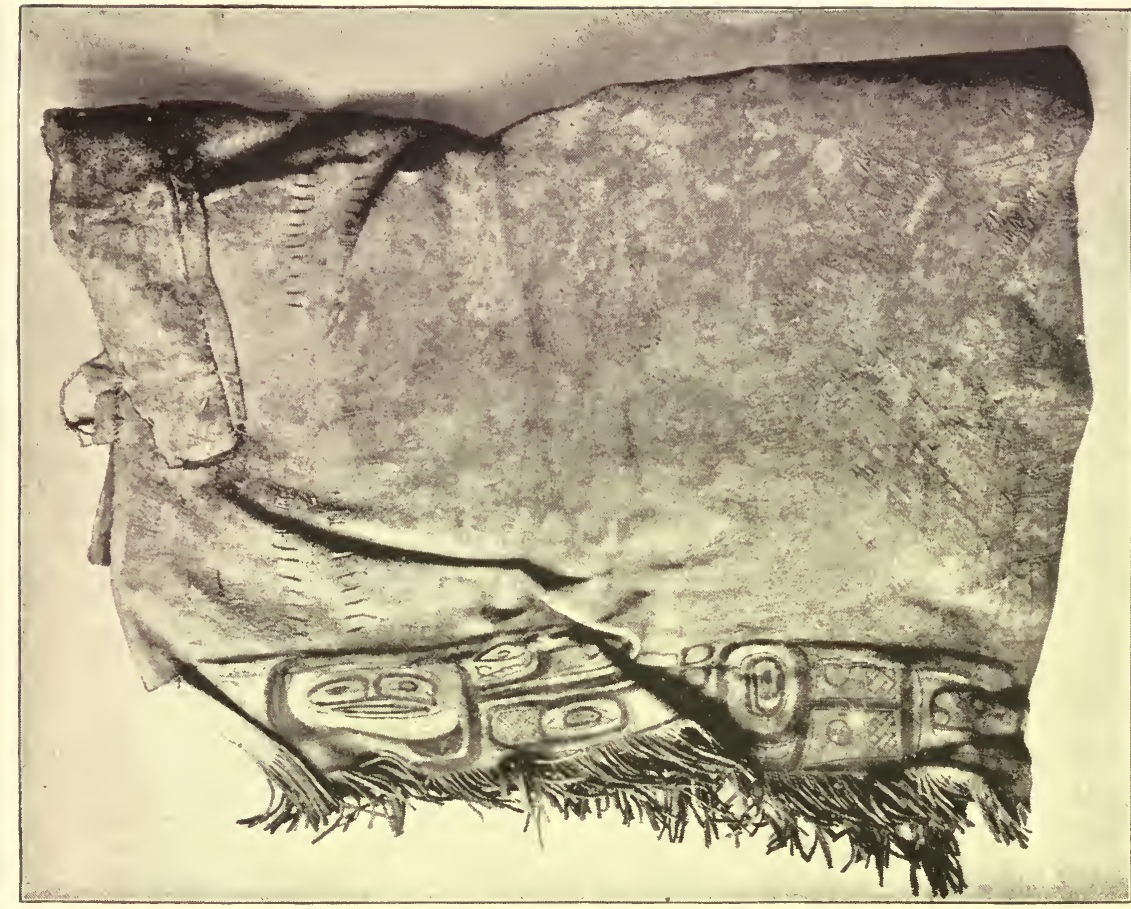

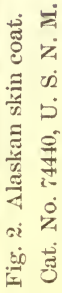

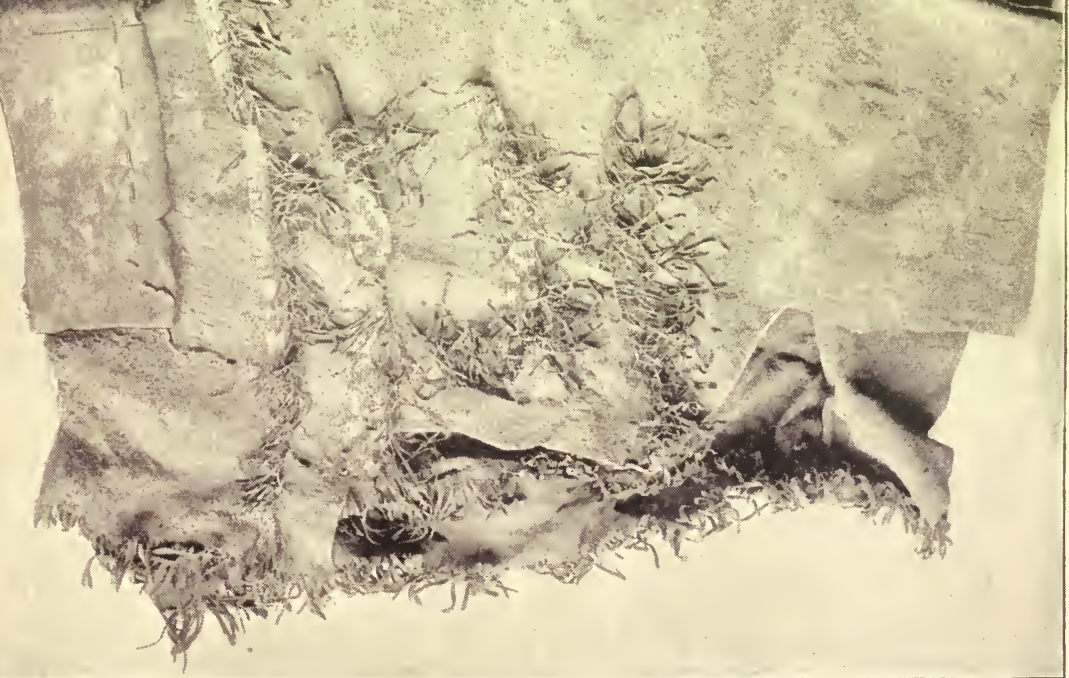




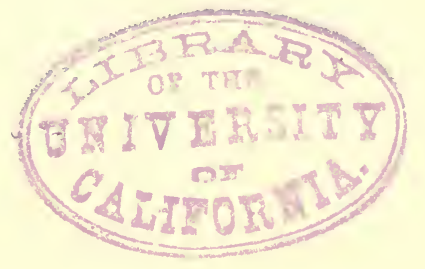


Padded armor has been of widespread adoption. In Mongolian countries it survived to a recent date. The Korean armor (fig. 5*) will give an idea of this type.

\section{Prescott says, in reference to the Peruvian armor:}

Men's bodies were protected by casques made either of wood or the s'rins of wild animals, and sometimes richly decorated with metal and with precious stones surmounted by the brilliant plumage of the tropical birds. * * * Men's defensive armor consisted of a shield, or buckler, and a close tunic of quilted cotton, in the same manner as with the Mexicans.t

Probably not very different from the cuirass of hide of the northern tribes.

Hansard tells us the Spaniards invented felt covering for their horses as a protection against Floridan arrows. $\ddagger$ He also states that-

The Spaniards, who fight on horseback with the Indians of those provinces, carry a doublet well lined with cotton wool. $\oint$

It may be surmised that the Spaniards introduced this style of armor both into Mexico and Peru.

Dr. Brinton, in his "A merican Race," says of the Tarascos of Michoacan :

Nowhere else do we find such complete defensive armor. It consisted of helmet, body pieces, and greaves for the legs and arms, all-of wood, covered neatly with copper or gold plates, so well done that the pieces looked as if they were of solid metal.

The following excerpts, arranged geogruphically, describing armor from other tribes not represented by extant specimens, are introduced here to show the range of armor in America.

The Nass Indians of the Tsimshian stock follow the other stocks on the Northwest Coast in that-

Their war garments were formed of 2,3, or more folds of the strongest hides of the land animals they were able to procure. In the center was a hole sufficient to arlmit the head and left arm to pass through, the mode of wearing them being over the right shoulder and under the left arm. The left' side of the garment is sewed up, but the right side remains open; the body is, however, tolerably well protected,

* This consists of a coat, helmet, and wide belt made up of many thicknesses of coarse cotton cloth covered with yellow stuff. The coat is made up of two wide flaps connected by a band which passes over the left shoulder. These flaps are cut out to fit the neck, and are tied at either side. A plastron of cloth is hung over the chest. The surface of portions of the coat is printed with Sanserit dharani, or prayers for victory. A belt resembling those worn by Korean women at the present time, but much thicker, is tied around the waist. 'The helmet is padded, and is stiffened by four perpendicular bands of iron riveted through the eloth and terminating in a brass ball at the apex. Visor, small; wide and heavy épaules, one at either side at the back. The helmet has also Sanscrit dharani written upon it. Length of coat, 34 inches; width, 30 inches; length of belt, 54 inches; width, 11 inches; height of helmet, 12 inches. (Cat. No. 128344 U.S. N. M. Korea. Deposited by Dr. G. Brown Goode )

+ Presscott, Conquest of Peru, 1, p. 67.

$\ddagger$ Hansard, History of Archery, p. 23.

$\S$ Benzoni, History of the New World, Hakluyt Soc., p. 8. 
and both arms are left at liberty for action. As a further security, on the part which covers the breast they sometimes fix on the inside thin laths of wood.*

\section{On Vancouver Island the Nootkas make use of-}

A thick tanned leather mantle, doubled, and appears to be the skin of an elk or buffalo. Thus is so contrived as to cover the breast quite up to the throat, part of it falling down to the heels. This garment is sometimes.very curiously painted, and is not only strong enough to resist, but, as we understand from them, spears could not penetrate it. So it may be considered their complete defensive armor. $t$

The Chinooks of the Columbia River use skin and rod armor. Ross says, in reference to the former, their war garments are of two kinds; one is termed clemal, of elk skin, dressed and worked to the thickness of nearly half an inch, and arrow proof. The clemal nearly covers the whole body, with an opening left on the right side to allow the arm free action in combat. (Ross, Alex., Advent., etc., on the Oregon or Columbia River. Lond., 1849, p. 89.)

\section{Franchere says of the Columbian River tribes:}

For defensive armor they wear a cassock or tunic of elk skin, double, descending to the ankles, with holes for the arms. It is impenetrable for their arrows, which can not pierce two thicknesses of leather; and as their heads are also covered with a sort of helmet, the neck is almost the only part in which they can be wounded. They have another kind of corselet made like the corsets of our ladies, of splinters of hard wood interlaced with nettle twine. The warriors who wear this eurious dress do not use the tunic of elk skin. He is consequently less protected, but a good deal more free, the said tunic being very heavy and very stiff. $\ddagger$

Passing eastward, Lewis and Clarke, when speaking of the Shoshoni of the Rocky Mountains, at the head of the Missouri River, remark:

They have a kind of armor, something like a coat of mail, which is formed by a great many folds of dressed antelope skins, united by means of a mixture of glue and sand. With this they cover their own bodies and those of their horses, and find it impervious to the arrow. $\$$

Mr. Dorsey informs me that there is reason to believe that the Pawni formerly employed a kind of hide cuirass and a defensive helmet, and as Du Pratz states that the Padoucas (Comanches) "cover their horses with dressed leather (probably bison hide), hanging down quite round, which secures them from darts," it is perhaps permissible to infer that their riders were protected in the same way.

In that wonderful origin-epic of the Navajoes the Indian singer chants to Dr. Matthews of "suits of armor made of several layers of buckskin. The warriors in those days wore such armor, but they wear it no longer." ||

* Vancouver, Voyage, Vol. II., p. 339.

† Cook's Voy., Vol. II., p. 246.

$\ddagger$ Franchere, Gabriel, Narrative of a Voyage to the Northwest Coast of America. New York, 1854, p. 253.

$\S$ Lewis and Clarke, Allen ed., Vol. I, 425, 1814.

\| Matthews, Washington, The Mountain Chant. Annual Report of this Bureau of Ethnology, 1883-'84, p. 73. 
Among the Pucblo tribes "they also wore cuirasses of elk or bison skin, or of padded cotton and yucca, and carried round shields of basketry of heavily and closely netted cotton, or of thick rawhide, symbolically painted." *

Coming to the great civilizations of ancient Mexico, Baneroft says of the Nahua Indians of Mexicc:

The chimalli, or Mexican shield, was made of varions materials and of divers forms, sometimes rounded and sometimes oval; sometimes rounded on the lower side. It was commonly constructed of flexible bamboo canes bound firmly together and covered with hide. The face of the shield was ornamented according to the rank and taste of the wearer; that of a noble was generally covered with thin plates of gold, with a heavy boss in the center. In Tabasco and along the coast tortoise shells inlaid with gold, silver, or copper were commonly used as shields. Reeds, grass, hides, or 'nequen cloth, coated with india rubber, served to protect an Aztec common soldier. Some shields were of an ordinary size; others were intended to cover the entire body, and were constructed so that when not in use they could be folded up and carried under the arm. (The body armor of the nobles and higher grades of warriors consisted of a breastplate made of quilted cotton, one or two fingers in thickness, called "ichcahuipilli." Over this was a thick cotton coat which covered part of the arms and thighs, made in one piece, fastened behind and decorated with feathers of the color of the company's uniform. The cotton armor was completely arrow proof. Arm and leg guards made of wood, covered with leather or gold plates and trimmed with feathers, and of the same material, shaped and painted to represent the head of a tiger, serpent, or monster with mouth open and teeth bared, complete the defensive armor. $t$

\section{A gain, in treating of the Toltecs, Veytia relates:}

The body armor worn by the principal warriors was made of double cloth padded with cotton. It differed from that of the Astecs, reaching down the ankles, and was worn over a thin white tunic. The private soldier painted the upper part of the body to represent armor, but from the waist to the thighs they wore short drawers, and over them fastened around the waist a kind of kilt that reached to the knee, and availed them somewhat for defense. Across the body was a sash made of feathers that passed from the right shoulder to the left side of the waist. $\ddagger$

Cotton-padded armor seems to have been the principal type used in Mexico. Among the Mayas of Mexico-

In addition to shields the Mayas had for defensive armor garments of thicklyquilted cotton, called escaupiles, which covered the body down to the lower part of the thigh, and were considered impervious to arrows. $\oint$

There are a few references among the Isthmian tribes of the use of armor where the skin and rod types persist. Gabb says that the Bri Bris and Tiribis, Costa Rica, use "an iron-headed lance with shaft barely 4 feet long. Round shields were carried on the arm, made of the thickest part of the hide of the tapir." |

* Extract from article "Pueblos," by F.H. Cushing, to be published in Johnson's Cyclopædia.

† Bancroft, H. H., Native Races of the Pacific States, Vol. II., p. 407.

$\ddagger$ Veytia, Hist. Ant. Mej., Tom. I, pp. 289-90.

\$Bancr 't, op. cit., I, p. 655 .

\| Gabb, A. M., Indians of Costa Rica, p. 516, Proc. Am. Philos. Soc., Aug. 20, 1875. 
The Mosquito Indians of Honduras also employed armor. Bancroft says:

Armor is made of plaited reeds covered with tiger skins and ornamented with feathers ; besides this they employ a breastplate of twisted cotton. *

Entering the continent of South America we find that-

The Abipones are nnacquainted with shields and targets, but they cover greatest part of their bodies with a sort of defense made of an undressed anta's hide, a tiger skin being sewed either in the in or out side; it is open in the middle, that the head may come through; and extended on each side as far as the elbows and middle; it is impenetrable to common arrows, but not to spears and bullets.t

In the vast continent of South America there are only scattering references to the use of armor. In the southern extremity, where the phase of life assumes a resemblance to that of our North American tribes, we find well-known forms of armor. The cavalry of the Araucanians is "armed with swords and lances; formerly used bows and slings. The soldiers are not clothed in uniform, according to the European custom, but all wear beneath their usual dress cuirasses of leather, hardened by a peculiar mode of dressing; their shields and helmets are also made of the same material." $\ddagger$

The Patagonians also wear a helmet with coat of mail, made of several folds of hide, and have a shield of bull's hide for use on foot.ई Their weapons are bows, lances, bolas, and clubs.

\section{EASTERN AREA.}

There is sufficient historical evidence that the defensive weapons of the east coast were similar to those of the west coast. The lakes and rivers with short portages rendered communication easy across this vast distance, and points out a great line of migration both of peoples and inventions. This is shown by the following reference:

Some sixty or seventy years ago a party of Iroquois, having crossed the Rocky Mountains, reached L. Tatha in two wooden canoes, which at once excited the covetousness of a band of Carriers, who killed the strangers for the sake of their canoes. These having been brought here (Stuart's Lake) served as models for the building of the first home-made "dugouts." $\|$

On the Atlantic slope there is abundant evidence to show that the Iroquois used body armor. Cartier (Hakluyt Voy., Vol. III, London, 1810), speaking of the Toudamani (Iroquois, probably Onondaga and Seneca) says :

Also they showed us the manner and making of their armor; they are made of cordes and wood, finely and cunumgly wrought together.

* Bancroft, op. cit., I, p. 723.

† Waitz. Anthropologie, Vol. Ir, p. 361.

†'Thompson, G. A. Alcedo's Geogr. and Hist. Dict. of America. Lond., 1812, Vol. I, p. 407.

§ Falkuer. Description of Patagonia, p. 129.

\|Morice, A. G. Proc. Canadian Inst., Oct., 1889, p. 131. The Carriers previously had birch-bark canoes. 
Lafitau, whose famous work "Moeurs des Sauvages Ameriquains," was published in 1724, gives a more detailed account of the defensive armor of the tribes of the northeastern part of the present United States and of Canada, probably referring chiefly to the Iroquois and Huron, with whom he was most familiar. He says (Vol. II, p. 197):

Their cuirasses were a tissue of wood, or of small sticks of reed cut of proportionate lengths, strongly pressed against each other, woven and enlaced very neatly with small cords made of deer skin. They had cuissards and brassards (defensive coverings for the thighs and arms) of the same material. These cuirasses were proof against arrows armed with bone or stone, but not against those mounted with iron.

Charlevoix says of the Iroquois:

Most had no defensive weapon, but when they attacked any intrenchment, they covered their whole body with small, light boards. Some have a sort of cuirass or breastplate of small, pliable rings, very neatly worked. They had even formerly a kind of mail for the arms and thighs, made of the same materials. But as this kind of armor was found not to be proof against firearms, they have renounced them withont putting anything in their place. *

Sagard says that the Hurons (Iroquois) had armor made of wood. $\dagger$ Champlain also describes the Iroquois' armor as made of wood and thread. $\neq$ A plate in the same volume shows a warrior in armor. Wooden breastplates were worn.ई Copper breastplates have been found, like the gold breastplates of Peru. $\|$ One has been described as a plate of rich copper, in length a foot, in width half a foot, for a breastplate. $\uparrow$ Lucian Carr thinks these breastplates were for ornament, like those found in the Ohio mounds. The size of the New England breastplates, however, would render them a tolerable protection if used as a plastron.

The only reference to eastern skin armor is of the Mohawks, who "wear sea-horse skins and barks of trees made by their art as impenetrable, it is thought, as steel, wearing a headpiece of the same." **

In reference to the Virginia Indians, Hariot says:

They are a people clothed with loose mantles made of Deere skins, and aprons of the same rounde abont their middles; all e'se naked; of such a difference of statures only as wee in England; having no edge tooles or weapons of yron or steele to offend us withall, neither know they how to make any: those weapõs that they have are onlie bowes made of Witch hazle, and arrowes of reeds; flat edged truncheons also of wood about a yard long, neither have they any thing to defend themselves but targets made of barcks; and some armours made of stickes wickered together with thread. $t+$

* Charlevoix, P. F. X. de, Vol. r, 338. Loud., 1761.

† Voyage des Hurons, I, p. 144.

$\ddagger$ Champlain, I, p. 201. Paris, 1830 .

$\S$ Hakluyt's Voyages, III, p. 305.

\|Breastplate of Gold. Peru. J. Anthrop. Inst., Vol. xvir. No. 3. Feb., 1889.

I Archer account, Griswold's Voyages, p. 75 in Vol. vilI, 35 Mass. Historical Collection.

** New England Prospect, p. 65.

t† A lorief and true report of the new-found land of Virginia, Thomas Hariot, 1585, De Bry, p. 24. 
I have not met with accounts of armor among the southern tribes, as the Muskoki group and others, but should hesitate to conclude that the idlea of a defense for the body against arrows and spears, other than the shields, had not occurred to these progressive tribes.

As a rule, the helmet is the most striking and prominent portion of body armor.

War bounets and various head coverings of the American aborigines, in many cases, may be classed with helmets. The function of the helmet, after protection, is to adorn the head, but an almost constant feature is that of inspiring fear by grotesque or horrid construction. Thus the helmet is connected with the mask.

There is a large series of Northwest Coast helmets in the National Museum. (See pl. 9.) They are always of wood, fitting the head, carved above to represent animals, grotesque faces, etc., always painted and sometimes carved with a rim like a hat. There is in the collection one helmet of wood covered with leather. Another fine helmet (Cat. No. 168157) from the Taku Indians of southern Alaska is carved from solid wood in form of the Japanese type, called Kabuto or pot helmet. The front is finely worked out into the form of a grotesque face, with deep furrows across the nose, cheeks, and forehead, like New Zealand tattooing, and painted green, red, and black. The ears at the side of the mask are accurately executed. The mask projects above the crown of the helmet and the upper ridge is studded with wooden pegs, which once held a fringe of sea-lion whiskers or bristles. Pegs are also seen on the chin and lips. The rear and rim of the helmet bear a totemic-painted carving in low relief.

Throngh the inner edge of the rim of the helmet four slanting holes have been bored. These were probably for the passage of thongs which held a mask-visor before the face.

Visors were worn, carved to represent a face, or bowed visors ingeniously made by cutting deep searfs in the wood, allowing it to bend. On the interior of this style of visor was a projecting grommet which - was taken between the teeth, holding the visor in place. Other masklike visors were suspended from the helmet with cords and a couvre de nuque was often attached to the back.

The only other survival of helmets in North America is among the Pueblo Indians, where they appear in ceremonies, in the form of mask helmets.

A few historical notices have been given of the helmets used by the eastern Indians.

A summary of the main conclusions which may be drawn from the foregoing paper will show:

(1) That a majority of the American tribes had advanced to the stago where they made use of body armor-that is, were sedentary tribes.

(2) This also implies differentiation of weapons rendering armor necessary, or the migration of the invention, or independent inventic a. 
e coat of thick skin which has appeared at all times and places $y$ have arisen independently, following the prime idea of the conhitance of weapon and antiweapon, but-

3) Plate armor in America is a clear case of the migration of invennn, its congeners having been traced from Japan northeastward frough the Ainos, Giliaks, and Chukchis, across Bering Strait by the intervening islainds to the western Eskimo. Here the armor spread southward from the narrowest part of the strait, passing into the slat armor of the Northwest Coast, which is possibly a development of the plate idea. The plate armor also may have spread to the eastern coast of North America. Hence it appears to be conclusive that plate armor in America had Asiatic origin. The date of this introduction is not considered.

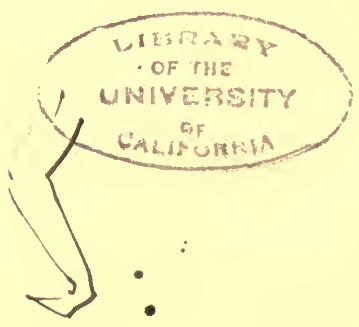




\section{UNI I LRSITY OF CALIFORNIA LIBRARY BERKELEY}

Return to desk from which borrowed. This book is DUE on the last date stamped below.

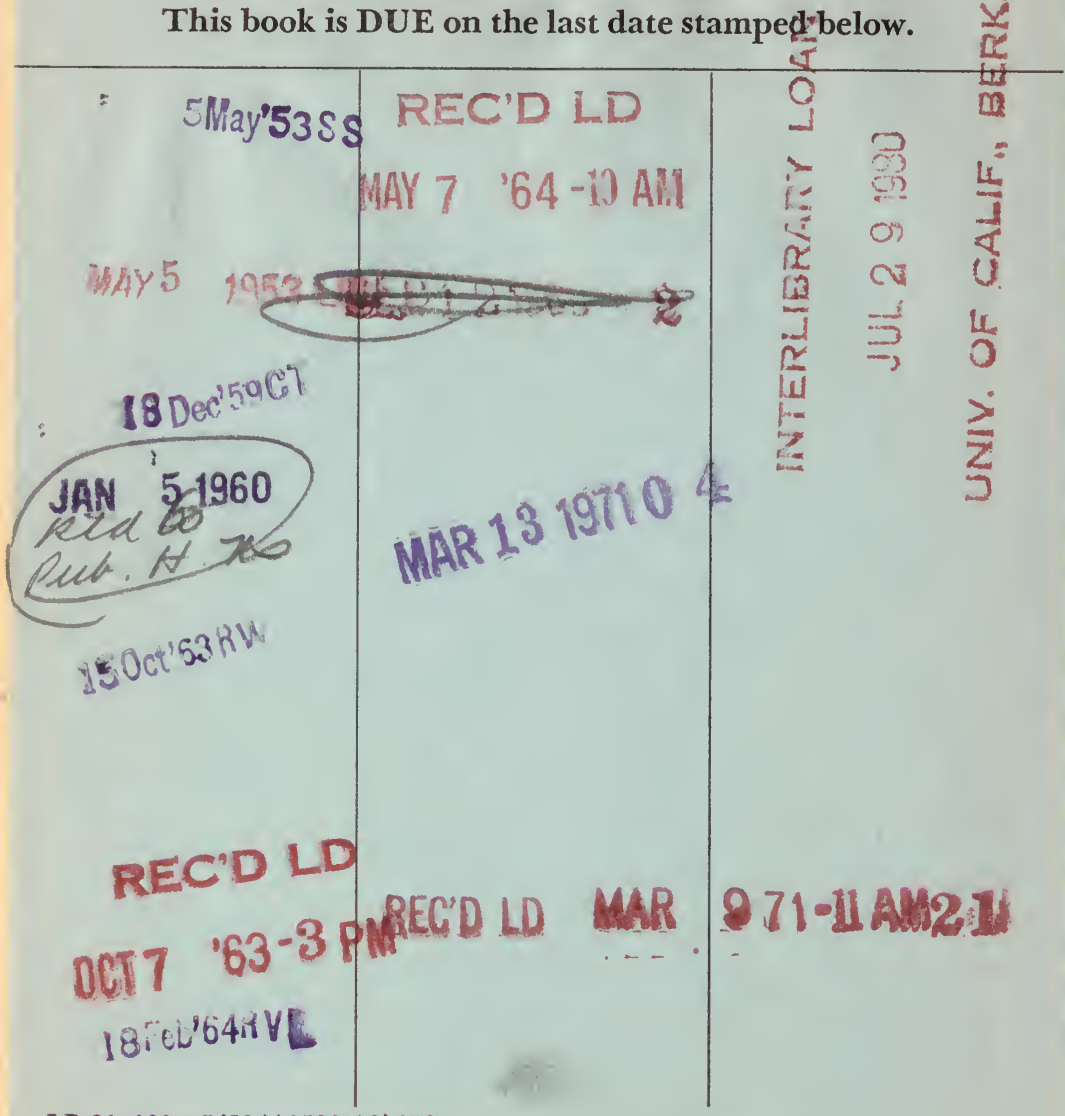


1

20.

1.

$x^{3} y=$

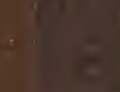

is -5

k $=-7$

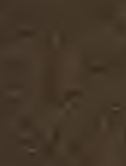

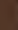

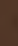

is 
1)

-
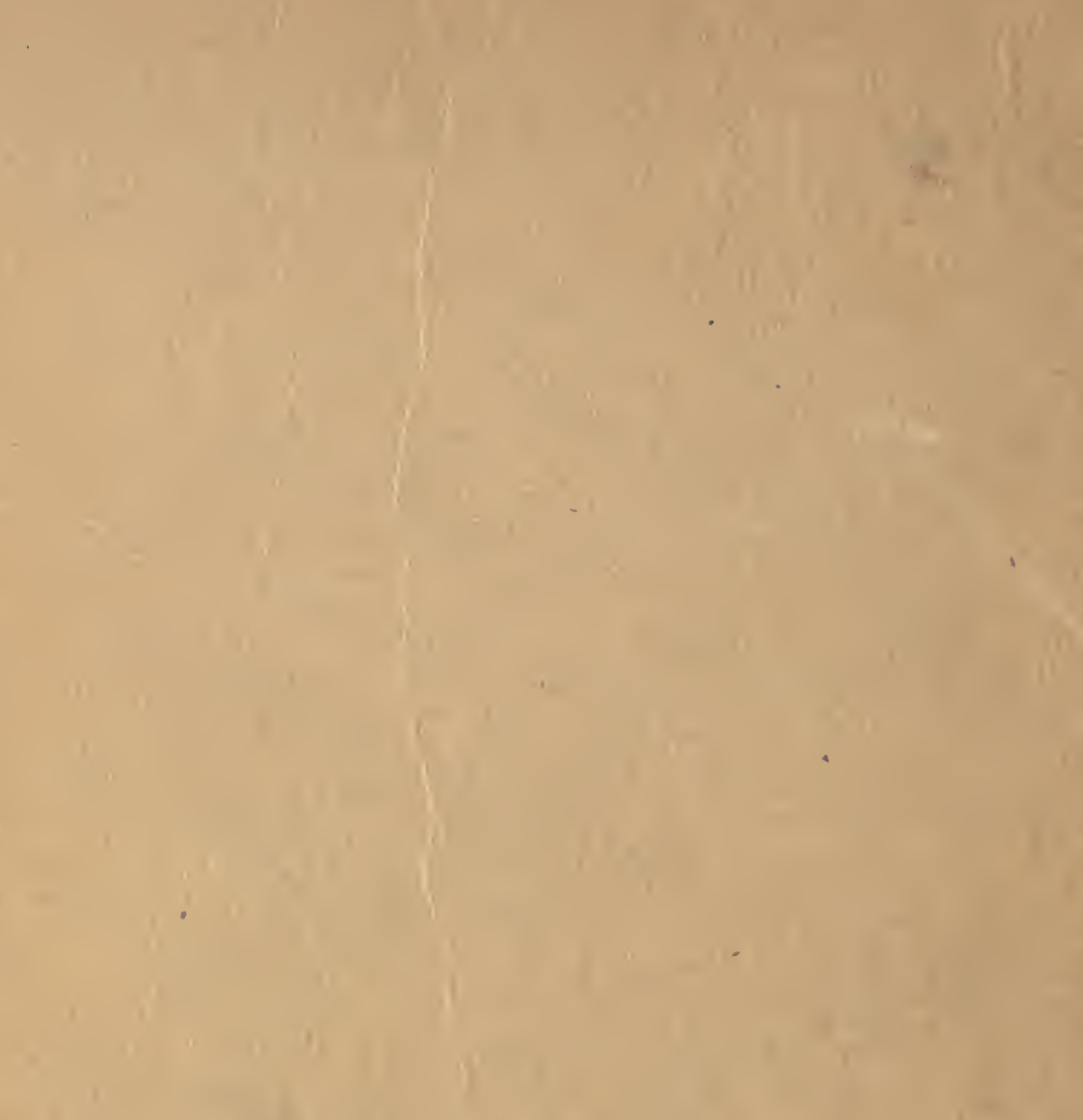

1

-

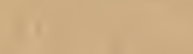

$-$

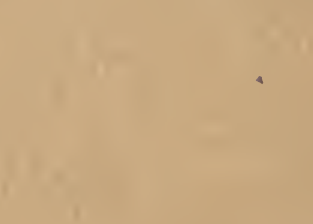

